
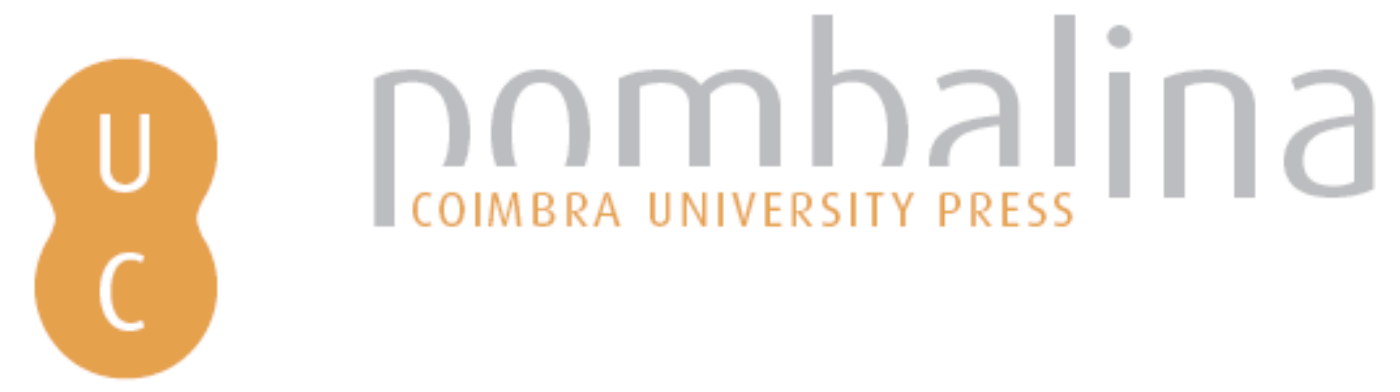

\title{
Las competencias documentales de los profesionales del Periodismo y la Comunicación: un estudio comparativo de los programas formativos de las universidades españolas y portuguesas
}

Autor(es): $\quad$ Agustín Lacruz, María del Carmen; Ubieto Artur, María Isabel

Publicado por: Imprensa da Universidade de Coimbra

URL persistente:

URI:http://hdl.handle.net/10316.2/31928

DOI:

DOI:http://dx.doi.org/10.14195/978-989-26-0319-3_32

Accessed : $\quad$ 26-Apr-2023 14:55:02

A navegação consulta e descarregamento dos títulos inseridos nas Bibliotecas Digitais UC Digitalis, UC Pombalina e UC Impactum, pressupõem a aceitação plena e sem reservas dos Termos e Condições de Uso destas Bibliotecas Digitais, disponíveis em https://digitalis.uc.pt/pt-pt/termos.

Conforme exposto nos referidos Termos e Condições de Uso, o descarregamento de títulos de acesso restrito requer uma licença válida de autorização devendo o utilizador aceder ao(s) documento(s) a partir de um endereço de IP da instituição detentora da supramencionada licença.

Ao utilizador é apenas permitido o descarregamento para uso pessoal, pelo que o emprego do(s) título(s) descarregado(s) para outro fim, designadamente comercial, carece de autorização do respetivo autor ou editor da obra.

Na medida em que todas as obras da UC Digitalis se encontram protegidas pelo Código do Direito de Autor e Direitos Conexos e demais legislação aplicável, toda a cópia, parcial ou total, deste documento, nos casos em que é legalmente admitida, deverá conter ou fazer-se acompanhar por este aviso.

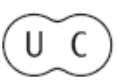


Maria Manuel Borges

Elias Sanz Casado

Coordenação

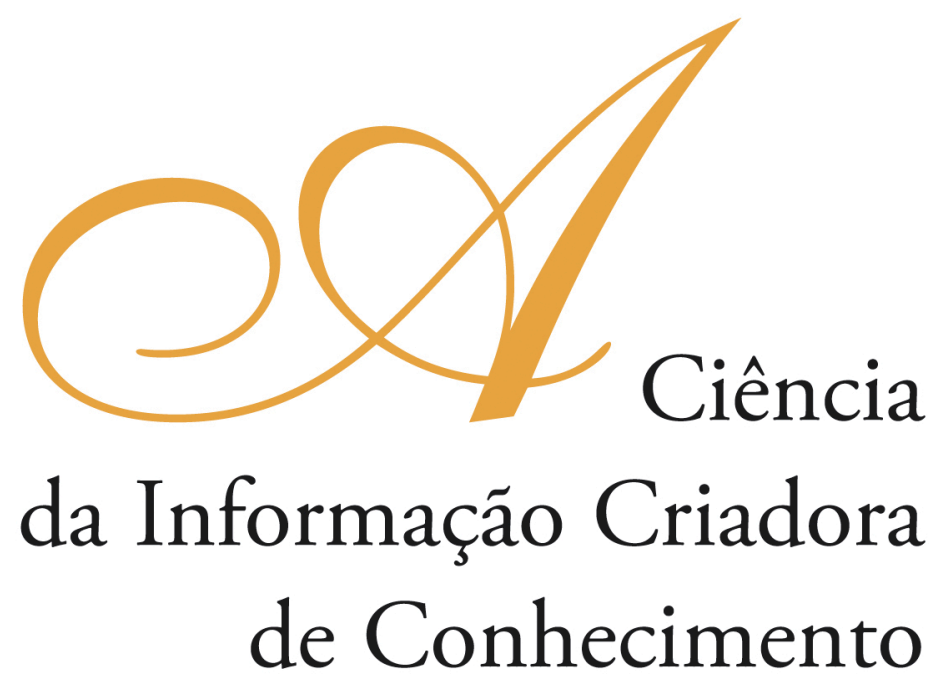

Vol. I

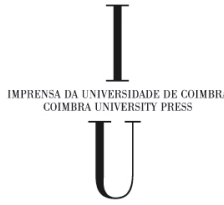

- COIMBRA 2009 


\title{
Las competencias documentales de los profesionales del Periodismo y la COMUNICACIÓN: UN ESTUdIO COMPARATIVO DE LOS PROGRAMAS FORMATIVOS DE LAS UNIVERSIDADES ESPAÑOLAS Y PORTUGUESAS
}

\author{
María del Carmen Agustín Lacruz \\ Universidad de Zaragoza (Espanha) \\ María Isabel Ubieto Artur \\ Universidad de Zaragoza (Espanha)
}

\section{Resumen}

En un contexto en el que las universidades españolas y portuguesas están completando la adaptación de sus planes de estudio a las directrices establecidas por el proceso de convergencia hacia un espacio Europeo de Educación superior en el que se favorece la movilidad de los estudiantes y de los profesionales mediante el reconocimiento mutuo de sus capacidades profesionales, el propósito de este trabajo es analizar la forma en que las competencias técnicas de índole documental, se reflejan en los programas formativos de las universidades de ambos países. Se estudia el marco normativo y académico de cada país, se identifican todas las universidades en las que se ofertan las titulaciones de Periodismo y/o Comunicación, se analizan la manera en que se formulan los objetivos de aprendizaje, las competencias profesionales y los programas de contenidos formativos y se observan los elementos coincidentes y los diferenciadores. Se concluye con una valoración de los resultados obtenidos.

\begin{abstract}
The university in Spain and Portugal adapting their curricula to the European Higher Education Area. It promotes the mobility of students and professionals and recognizes their skills. The aim of this paper is to analyze the presence of skills in the documentary journalism studies in Spain and Portugal and examines the academic and policy framework in each country. It identifies all the universities in which there are studies in Journalism and Communication Sciences. Are analyzed and shown the learning objectives, skills, training programs and the similarities and differences.
\end{abstract}

\section{Introducción}

En la actualidad, la mayor parte de las universidades españolas y portuguesas están inmersas en el proceso de adaptación de sus planes de estudio a las directrices establecidas en el proceso de aproximación hacia un Espacio Europeo de Educación Superior (EEES). Este proyecto involucra a más de 40 estados europeos que comparten el objetivo común de alcanzar en el año 2010 un sistema de titulaciones universitarias flexible, comprensible y comparable, que permita incrementar las oportunidades laborales de los estudiantes y titulados europeos y favorecer su movilidad entre los países del continente. 
El EEES conlleva cambios importantes en los sistemas educativos universitarios de cada uno de los estados que participan. Estos cambios implican la reordenación de las enseñanzas universitarias y la flexibilización de la organización de las titulaciones para promover la diversificación curricular y permitir que las universidades aprovechen su capacidad de innovación, ofreciendo respuestas a las demandas de la sociedad en un contexto de constante transformación. Uno de los principales propósitos del EEES es hacer compatibles y transparentes los sistemas universitarios, sin homogeneizarlos. Esto significa que los planes de estudios de una misma titulación -o de titulaciones similaresno siendo necesariamente iguales, sí pueden ser objeto de reconocimiento mutuo.

Para favorecer dicho reconocimiento así como la comprensión sobre las competencias adquiridas en una determinada titulación, los títulos se acompañan del Suplemento Europeo al Título (SET), que facilita que las materias y asignaturas cursadas sean interpretables y reconocidas por todos los países constituyentes del EEES. El SET contiene información detallada sobre las materias, idiomas, créditos realizados, competencias adquiridas, resultados académicos y cualificación profesional del estudiante, con su nombre y apellidos. Es un documento específico con un formato común que otorga validez comunitaria al currículum académico desarrollado con el objetivo de hacer posible el reconocimiento de créditos entre las diferentes titulaciones del EEES y acreditar las capacidades adquiridas por el estudiante ante posibles empleadores.

En este contexto educativo orientado hacia el fomento de la movilidad mediante el reconocimiento de las capacidades profesionales, el propósito de este trabajo es analizar la forma en que las competencias técnicas de índole documental se reflejan en los programas formativos de las universidades portuguesas y españolas con estudios de Periodismo o Comunicación, en aras a facilitar el mutuo conocimiento de sus contenidos curriculares. Para ello, se estudia el marco normativo y académico de cada uno de los dos estados, se identifican todas las universidades en las que se ofertan estas titulaciones, se analizan los contenidos formativos y se observan los elementos coincidentes y los diferenciadores.

\section{El contexto jurídico: La consolidación del Espacio Europeo de Educación Superior}

El EEES ha sido concebido desde su origen como una herramienta conceptual y metodológica para construir la Sociedad del Conocimiento europea, cuyo objetivo es incrementar el empleo ligado a la denominada "economía del conocimiento" y convertir a nuestro continente en un foco de atracción para estudiantes, profesores y empleadores, poniendo freno a la "fuga de cerebros" hacia otras zonas del planeta.

Implica un complejo programa de acciones pautadas en el tiempo que se traducen en cambios importantes en los sistemas universitarios de cada uno de los estados participantes. Estos cambios han de responder a las decisiones adoptadas por los responsables políticos de la educación superior de los países implicados en el proyecto, en las reuniones que se han ido manteniendo regularmente desde 1999, constituyendo el denominado "proceso de Bolonia". Estas decisiones y acuerdos se han dado a conocer en forma de "Declaraciones" y "Comunicados" y posteriormente se han ido trasponiendo a la legalidad propia de cada estado, constituyendo el marco legal en el que se desenvuelven las actividades desarrolladas por las universidades. 
El elevado número de estados participantes en el proceso de convergencia europea, así como las diferencias educativas, socio-culturales, políticas y económicas entre ellos provoca notables diferencias y disimilitudes en su desarrollo. Estas se explican en parte, porque el proceso de armonización académica se caracteriza por un fuerte compromiso político asumido por los estados participantes, y simultáneamente, por la carencia de un marco normativo jurídico vinculante de Derecho Internacional o Comunitario europeo.

El lado positivo de esta situación es que existe una gran flexibilidad en las propuestas y en los modelos que cada estado participante adopta. Por el contrario, el lado negativo pone de manifiesto la carencia de precisión conceptual, procedimental y temporal del proceso, lo que ha dado lugar a cierta dosis de inseguridad y confusión en los agentes de la implantación, así como al surgimiento de movimientos reactivos a su implantación que han logrado cierta repercusión mediática.

El proceso de adaptación al EEES en España -y en buena medida también en Portugal- se ha caracterizado por coincidir en el tiempo con un periodo complejo de reformas tanto en el marco legal que organiza la enseńanza superior, como en la normativa interna que regula el funcionamiento y la estructura de cada universidad. Este conjunto de elementos explica, en parte, que el proceso de Bolonia haya supuesto un conjunto de normas legales muy variadas, que se recogen ordenadas cronológicamente en la Tabela 1.

Tabela 1 - Marco legal regulador del EEES en España y Portugal

\begin{tabular}{|c|c|c|c|}
\hline Fecha & Estado & Norma Legal & Materias \\
\hline 1997 & Portugal & $\begin{array}{l}\text { Ley de Bases do Sistema Educativo } \\
\text { n. }{ }^{\circ} 46 / 86 \text {, de } 14 \text { de, modificada } \\
\text { por la Ley n. } .^{\circ} 115 / 97 \text {, de } 19 \text { de } \\
\text { septiembre }\end{array}$ & $\begin{array}{l}\text { Organización del sistema } \\
\text { universitario portugués }\end{array}$ \\
\hline 2001 & Espańa & $\begin{array}{l}\text { Ley Orgánica 6/2001, de } 21 \text { de } \\
\text { diciembre, de Universidades }\end{array}$ & $\begin{array}{l}\text { Organización del sistema } \\
\text { universitario español }\end{array}$ \\
\hline 2003 & España & $\begin{array}{l}\text { Real Decreto } 1044 / 2003 \text {, de } 1 \mathrm{de} \\
\text { agosto, por el que se establece el } \\
\text { procedimiento para la expedición } \\
\text { por las universidades del } \\
\text { Suplemento Europeo al Título. }\end{array}$ & Suplemento Europeo al Título \\
\hline 2003 & España & $\begin{array}{l}\text { Real Decreto } 1125 / 2003 \text {, de } 5 \text { de } \\
\text { septiembre, por el que se establece } \\
\text { el sistema europeo de créditos } \\
\text { y el sistema de calificaciones en } \\
\text { las titulaciones universitarias de } \\
\text { carácter oficial y validez en todo el } \\
\text { territorio nacional. }\end{array}$ & $\begin{array}{l}\text { Sistema europeo de créditos. } \\
\text { Sistema de calificaciones. }\end{array}$ \\
\hline 2005 & Portugal & $\begin{array}{l}\text { Decreto-Lei n. }{ }^{\circ} 42 / 2005 \text {, de } 22 \text { de } \\
\text { Fevreiro }\end{array}$ & $\begin{array}{l}\text { Principios reguladores dos } \\
\text { instrumentos para a criação do } \\
\text { espaço europeu do ensino superior. } \\
\text { Emissáo do Suplemento ao } \\
\text { Diploma (SD). ECTS. }\end{array}$ \\
\hline 2005 & Portugal & $\begin{array}{l}\text { Decreto-Lei } \text { n. }^{\circ} \text { 67/2005, de } 15 \text { de } \\
\text { Março de } 2005\end{array}$ & Mestrados «Erasmus Mundus» \\
\hline
\end{tabular}




\begin{tabular}{|c|c|c|c|}
\hline 2005 & España & $\begin{array}{l}\text { Real Decreto } 309 / 2005 \text {, de } 18 \text { de } \\
\text { Marzo, por el que se regulan las } \\
\text { condiciones de homologación y } \\
\text { convalidación de títulos y estudios } \\
\text { extranjeros de Educación Superior. }\end{array}$ & $\begin{array}{l}\text { Homologación y convalidación } \\
\text { de títulos y estudios superiores } \\
\text { extranjeros }\end{array}$ \\
\hline 2005 & Portugal & $\begin{array}{l}\text { Despacho } n^{\circ} 10543 / 2005\left(2^{a}\right. \\
\text { Serie), de } 11 \text { de Mayo de } 2005\end{array}$ & $\begin{array}{l}\text { Normas técnicas para la } \\
\text { presentación de las estructuras } \\
\text { curriculares y de los planes de } \\
\text { estudios de los cursos superiores }\end{array}$ \\
\hline 2005 & Portugal & $\begin{array}{l}\text { Lei n. }{ }^{\circ} 49 / 2005 \text {, de } 30 \text { de Agosto } \\
\text { de } 2005\end{array}$ & $\begin{array}{l}\text { Condiçóes de acesso ao ensino } \\
\text { superior para os que nele nấo } \\
\text { ingressaram na idade de referência } \\
\text { a adopção do modelo de } \\
\text { organizaçáo do encino superior em } \\
\text { três ciclos; } \\
\text { A transição a um sistema de ensino } \\
\text { baseado no desenvolvimento } \\
\text { de competências; A adopçáa } \\
\text { do sistema europeu de créditos } \\
\text { curriculares (ECTS) }\end{array}$ \\
\hline 2006 & Portugal & Decreto-Lei no 64/2006 & $\begin{array}{l}\text { Regime especial de acesso ao } \\
\text { ensino superior para maiores de } \\
23 \text { anos }\end{array}$ \\
\hline 2006 & Portugal & $\begin{array}{l}\text { Decreto-Lei n. }{ }^{\circ} 74 / 2006 \text {, de } 24 \text { de } \\
\text { Março, alterado pelo Decreto-Lei } \\
\text { n. }{ }^{\circ} 107 / 2008 \text {, de } 25 \text { de Junho }\end{array}$ & $\begin{array}{l}\text { Novo modelo de organizaçáo do } \\
\text { ensino superior no que respeita aos } \\
\text { ciclos de estudos: graus e diplomas } \\
\text { de ensino superior }\end{array}$ \\
\hline 2007 & Espańa & $\begin{array}{l}\text { R.D. } 189 / 2007 \text {, de } 9 \text { de } \\
\text { febrero, por el que se modifican } \\
\text { determinadas disposiciones del } \\
\text { R.D. } 56 / 2005 \text {, de } 21 \text { de enero, } \\
\text { por el que se regulan los estudios } \\
\text { universitarios oficiales de posgrado }\end{array}$ & Estudios de postgrado \\
\hline 2007 & España & $\begin{array}{l}\text { Ley Orgánica 4/2007, de } 12 \mathrm{de} \\
\text { abril, por la que se modifica la } \\
\text { Ley Orgánica 6/2001, de } 21 \text { de } \\
\text { diciembre, de Universidades }\end{array}$ & $\begin{array}{l}\text { Modificación de la organización } \\
\text { del sistema universitario español }\end{array}$ \\
\hline 2007 & Portugal & $\begin{array}{l}\text { Lei n. } .^{\circ} 62 / 2007 \text {, de } 10 \text { de } \\
\text { Setembro de } 2007\end{array}$ & $\begin{array}{l}\text { Regime jurídico das instituiçóes de } \\
\text { encino superior }\end{array}$ \\
\hline 2007 & España & $\begin{array}{l}\text { Real decreto } 1393 / 2007 \text {, de } 29 \text { de } \\
\text { octubre, por el que se establece } \\
\text { ordenación de las enseńanzas } \\
\text { universitarias oficiales. }\end{array}$ & $\begin{array}{l}\text { Ordenación de las enseńanza } \\
\text { universitarias }\end{array}$ \\
\hline 2008 & Portugal & $\begin{array}{l}\text { Portaria n. }{ }^{\circ} 30 / 2008 \text {, de } 10 \text { de } \\
\text { Janeiro de } 2008\end{array}$ & Regula o suplemento a o diploma \\
\hline 2008 & Portugal & $\begin{array}{l}\text { Decreto-Lei n. }{ }^{\circ} 107 / 2008 \text {, de } 25 \\
\text { de Junho de } 2008\end{array}$ & $\begin{array}{l}\text { Simplificaçáo e desburocratizaçáa } \\
\text { de procedimentos del novo modelo } \\
\text { de organizaçáo do ensino superior }\end{array}$ \\
\hline 2008 & España & $\begin{array}{l}\text { Real Decreto } 1509 / 2008 \text {, de } 12 \text { de } \\
\text { septiembre, por el que se regula el } \\
\text { Registro de Universidades, Centros } \\
\text { y Títulos. }\end{array}$ & $\begin{array}{l}\text { Registro de Universidades, Centros } \\
\text { y Títulos }\end{array}$ \\
\hline
\end{tabular}




\begin{tabular}{|l|l|l|l|}
\hline 2008 & Espańa & $\begin{array}{l}\text { Real Decreto 1892/2008, de 14 de } \\
\text { noviembre, por el que se regulan } \\
\text { las condiciones para el acceso a las } \\
\text { enseñanzas universitarias oficiales } \\
\text { de grado y los procedimientos } \\
\text { de admisión a las universidades } \\
\text { públicas españolas. }\end{array}$ & $\begin{array}{l}\text { Acceso a las enseñanzas de grado } \\
\text { Procedimientos de admisión }\end{array}$ \\
\hline
\end{tabular}

\section{El contexto académico: La consolidación de la documentación informativa como disciplina científica}

En este contexto, marcado por cambios de gran calado tanto de naturaleza normativa como de organización académica, la Documentación Informativa se ha consolidado como una disciplina específica dentro de las Ciencias de la Documentación.

Este hecho ha tenido lugar a lo largo de las tres últimas décadas como consecuencia, principalmente de dos factores relevantes: En primer lugar, a causa la creciente importancia que han adquirido las tareas documentales dentro los procesos de investigación que realizan los profesionales de la comunicación social para sustentar de forma adecuada las informaciones que elaboran; así como, en segundo lugar, debido a la inclusión de contenidos curriculares relacionados con los procesos de búsqueda, selección, sistematización y difusión documental dentro de los Planes de Estudio de las titulaciones relacionadas con las Ciencias de la Comunicación y de la Información ${ }^{1}$.

\footnotetext{
${ }^{1}$ En España, en el marco de la renovación de los Planes de estudio de muchas titulaciones universitarias que tuvo lugar en el comienzo de los años 90, se inició un proceso de remodelación curricular y de renovación de los contenidos que se plasmó en la consolidación de la asignatura Documentación Informativa como materia troncal de primer ciclo, con una carga lectiva de seis créditos, tres de carácter teórico y tres de carácter práctico. El contenido de esta asignatura se orientó hacia el estudio y análisis de los sistemas de documentación utilizados en los medios de comunicación y su impartición se adscribió a las áreas de conocimiento de Biblioteconomía y Documentación; Comunicación Audiovisual y Publicidad y Periodismo, respectivamente. Así se recoge en el Real Decreto 1427/1991, de 30 de agosto, por el que se establece el título universitario oficial de licenciado en Comunicación audiovisual y las Directrices generales propias de los planes de estudios conducentes a la obtención de aquel (BOE número 243 de 10/10/1991); en el Real Decreto 1428/1991, de 30 de agosto, por el que se establece el título universitario oficial de licenciado en Periodismo y las Directrices generales propias de los planes de estudios conducentes a la obtención de aquel (BOE número 243 de 10/10/1991) y en el Real Decreto 13868/1991, de 30 de agosto, por el que se establece el título universitario oficial de licenciado en Publicidad y Relaciones Públicas y las Directrices generales propias de los planes de estudios conducentes a la obtención de aquel (BOE número 234 de 30/09/1991).

En el año 2005, más de una década después, con el referente del proceso de convergencia europea, el Libro Blanco de los títulos de grado en Comunicación estableció como contenidos formativos mínimos en la titulación de Periodismo el "estudio de los sistemas de documentación para los medios informativos, y acceso y crítica de las fuentes para el periodismo” y en la titulación de Publicidad y Relaciones Públicas el "estudio de los fundamentos de documentación para el profesional de la comunicación publicitaria y de las relaciones públicas”. Véase Libro blanco. Títulos de grado en Comunicación. Madrid: ANECA, 2005 , p. 313 y 340, respectivamente, disponible en http://www.aneca.es/media/150336/libroblanco_ comunicacion_def.pdf.

En Portugal, los estudios de Periodismo (Jornalismo) se imparten en la Universidad de Coimbra, la Escuela Superior de Educación de Portoalegre, el Instituto Politécnico de Lisboa y el Instituto Superior de Administración, Comunicación y Empresa), con una duración de 4 cursos académicos. En otros centros
} 
A su vez, ambos acontecimientos han contribuido a fortalecer el estatus científico de dichas ciencias, al extender la fiabilidad, el rigor y la solvencia de las fuentes documentales desde las informaciones elaboradas hasta los propios medios de comunicación y, por otra parte, al hacer de la Documentación informativa una materia de investigación, capaz de reflexionar con métodos y técnicas científicas sobre su concepto, su alcance, sus instrumentos de trabajo y sus herramientas y técnicas específicas, haciendo de ella una auténtica disciplina científica. Ello ha supuesto que se hayan desarrollado tesis, tesinas, memorias de master y grado, así como diferentes trabajos de investigación dentro de los departamentos y centros universitarios y que se hayan creado revistas y publicaciones e instituido reuniones y eventos académicos para facilitar la adecuada difusión de las novedades entre la comunidad científica.

En la actualidad, la materia Documentación informativa forma parte de los contenidos comunes obligatorios de los Grados de Periodismo y Publicidad y Relaciones públicas, y de los contenidos optativos de un numeroso grupo de titulaciones pertenecientes a la macroárea de Ciencias Sociales. En general, se trata de asignaturas de marcado carácter instrumental, con una orientación muy práctica, cuyo objetivo es capacitar a los estudiantes para analizar documentación diversa, plantear estrategias de búsqueda, utilizar fuentes de información distintas y recuperar aquella información que les permita desarrollar la labor informativa propia de los periodistas. Suele estar orientada hacia la consecución del conocimiento instrumental de los procesos de análisis, recuperación y difusión de la información; el manejo de las herramientas e instrumentos que permiten llevar a cabo tales procesos de análisis, recuperación y difusión y finalmente, hacia la redacción de los productos documentales en que se concretan las actividades anteriores.

\section{Competencias documentales de los profesionales del periodismo y la comunicación}

\subsection{Objetivo}

Con el propósito de elaborar un estado de la cuestión que permita analizar comparativamente la forma en que las competencias técnicas de índole documental se reflejan en los programas formativos de las universidades de Espańa y Portugal, este trabajo se propone estudiar el marco normativo y académico de cada uno de los dos estados e identificar todas las universidades en las que se ofertan titulaciones de Periodismo y/o Comunicación para observar las características de los contenidos curriculares relacionados con la materia de Documentación informativa.

\footnotetext{
superiores portugueses, el Periodismo es una especialización o rama, que se cursa a partir del tercer año académico, dentro de la Licenciatura en Ciências da Comunicaçao o en Comunicaçao Social. Una información más detallada se puede consultar en Real Rodríguez, E. Formación y ejercicio profesional del periodista en la Espańa del siglo XXI dentro del marco de la unión europea. Defendida el 9 de marzo de 2004. Universidad Complutense de Madrid, 2004, disponible en http://eprints.ucm.es/tesis/inf/ucm-t27334.PDF. También en Libro blanco. Títulos de grado en Comunicación. Madrid: ANECA, 2005, p. 65-71.
} 


\subsection{Método de estudio}

Para conseguir el objetivo propuesto ha sido necesario realizar de forma sistematizada las tareas que se relacionan a continuación:

a) Compilar el marco normativo de cada país.

b) Inventariar las universidades que ofertan titulaciones relacionadas con las Ciencias de la Comunicación.

- Identificar cada uno de los centro de educación superior, su titularidad pública o privada, las titulaciones ofertadas y la presencia dentro de su oferta formativa de materias relacionadas con la Documentación informativa.

- Describir las características relevantes de las materias relacionadas con la Documentación informativa, recopilando la denominación de la asignatura, la titulación dentro de la que se incluye, el tipo de asignatura, el curso en el que se imparte y los créditos que tiene, así como la descripción de sus contenidos.

c) Analizar los datos, sistematizarlos y preparar tablas comparativas que los muestren de forma comprensiva.

El método de trabajo ha consistido, por tanto, en la elaboración de un estudio censal, que reúne los datos básicos de cada una de las universidades que ofertan titulaciones relacionadas con los estudios de Comunicación -Periodismo, Comunicación audiovisual y Publicidad y Relaciones Públicas-.

La recogida de información relativa a las universidades se ha realizado a lo largo del mes de julio del año 2009, mediante la consulta de la página web del Ministerio de Educación de España ${ }^{2}$ y la página web de la Dirección General de la Enseñanza Superior $^{3}$ (Direcção Geral do Ensino Superior), que depende del Ministerio de Ciencia, Tecnología y Enseñanza Superior ${ }^{4}$ de Portugal. La recogida de información relativa a las asignaturas también se ha realizado a lo largo del mes de julio del año 2009 mediante la consulta del BOE y de las páginas web de las universidades identificadas en la fase anterior ${ }^{5}$.

2 Véase el apartado ¿Qué estudiar? de la página web del citado Ministerio, disponible en http://www. educacion.es/educacion/universidades/educacion-superior-universitaria/que-estudiar-donde/universidadesespanolas.html.

${ }^{3}$ Disponible en http://www.dges.mctes.pt/DGES/pt/OfertaFormativa/Pesquisa/.

4 Véase http://www.mctes.pt/.

${ }^{5}$ Es necesario precisar que en el caso de las universidades españolas, se compilan todas las titulaciones que se ofertan para el curso académico 2009/2010. La necesidad de introducir las nuevas enseńanzas adaptadas al EES, conforme se van extinguiendo las titulaciones en curso implica la existencia de un periodo de transitoriedad caracterizado por la coexistencia de ambos modelos de titulaciones, puesto que conviven los antiguos títulos de Licenciado, que aún admiten estudiantes en su primer curso, como los nuevos títulos de Grado. Con respecto a estos últimos se recogen tanto los títulos de Grado ya implantados como aquellos que se han verificado y que "Tras la verificación por parte del Consejo de Universidades, de acuerdo con el artículo 26 del Real Decreto 1393/2007, resulta preceptiva la autorización por parte de la Comunidad Autónoma y la aprobación por el Consejo de Ministros, a propuesta del Ministerio de Educación, de su implantación e inscripción en el RUCT” y los “Títulos en proceso final de verificación. Tras la verificación por parte del Consejo de Universidades, de acuerdo con el artículo 26 del Real Decreto 1393/2007, resulta preceptiva la autorización por parte de la Comunidad Autónoma y la aprobación por el Consejo de Ministros, a propuesta del Ministerio de Educación, de su implantación e inscripción 


\section{Principales resultados}

A pesar de las dificultades que implica abordar este estudio en un momento de transición el que de "de facto" se produce el solapamiento de ofertas formativas pertenecientes a dos modelos de titulaciones distintas, es posible ofrecer una panorámica que arroja luz en dos direcciones:

\subsection{Alcance de la oferta formativa relacionada con el Periodismo y la Comunicación de las universidades espańolas y portuguesas}

Tabela 2 - Universidades espańolas y portuguesas con titulaciones relacionadas con el Periodismo, la Publicidad y la Comunicación, cuya oferta formativa incluye materias de Documentación Informativa

\begin{tabular}{|c|c|c|c|}
\hline Universidad & Titularidad & Titulación ofertada & $\begin{array}{l}\text { Materia } \\
\text { Documen- } \\
\text { tación } \\
\text { informativa }\end{array}$ \\
\hline $\begin{array}{l}\text { Escola Superior de } \\
\text { Educação Jean Piaget }\end{array}$ & Priv. & Educação e Comunicação Multimédia & No \\
\hline \multirow{3}{*}{$\begin{array}{l}\text { IE (Instituto Empresa) } \\
\text { Universidad }\end{array}$} & \multirow{3}{*}{ Priv. } & Grado en Comunicación & No \\
\hline & & Licenciado en Comunicación Audiovisual & $\mathrm{Si}$ \\
\hline & & Licenciado en Periodismo & $\mathrm{Si}$ \\
\hline $\begin{array}{l}\text { Instituto Politécnico } \\
\text { de Beja }\end{array}$ & Púb. & Educação e Comunicação Multimédia & No \\
\hline \multirow{3}{*}{$\begin{array}{l}\text { Instituto Politécnico de } \\
\text { Coimbra }\end{array}$} & \multirow{3}{*}{ Púb. } & Comunicação e Design Multimédia & No \\
\hline & & Comunicaçáo Organizacional & No \\
\hline & & $\begin{array}{l}\text { Comunicaçáo Organizacional (Regime } \\
\text { pós-laboral) }\end{array}$ & No \\
\hline $\begin{array}{l}\text { Instituto Politécnico de } \\
\text { Coimbra }\end{array}$ & Púb. & Comunicação Social & No \\
\hline \multirow{2}{*}{$\begin{array}{l}\text { Instituto Politécnico de } \\
\text { Leiria }\end{array}$} & \multirow{2}{*}{ Púb. } & $\begin{array}{l}\text { Comunicaçáo Social e Educação } \\
\text { Multimédia }\end{array}$ & No \\
\hline & & $\begin{array}{l}\text { Comunicaçáo Social e Educação } \\
\text { Multimédia (Pós-Laboral) }\end{array}$ & No \\
\hline \multirow{4}{*}{$\begin{array}{l}\text { Instituto Politécnico de } \\
\text { Lisboa }\end{array}$} & \multirow{4}{*}{ Púb. } & Audiovisual e Multimédia & No \\
\hline & & Jornalismo & No \\
\hline & & Publicidade e Marketing & No \\
\hline & & $\begin{array}{l}\text { Relaçoes Públicas e Comunicação } \\
\text { Empresarial }\end{array}$ & No \\
\hline $\begin{array}{l}\text { Instituto Politécnico de } \\
\text { Portalegre }\end{array}$ & Púb. & Jornalismo e Comunicação & No \\
\hline \multirow{2}{*}{$\begin{array}{l}\text { Instituto Politécnico de } \\
\text { Santarém }\end{array}$} & \multirow[b]{2}{*}{ Púb. } & Educação e Comunicaçáo Multimédia & No \\
\hline & & $\begin{array}{l}\text { Educaçáo e Comunicaçáo Multimédia } \\
\text { (Pós-Laboral) }\end{array}$ & No \\
\hline
\end{tabular}

en el RUCT”. Esta razón explica que no se disponga de la publicación de todos los Planes de Estudio correspondientes a algunos de los Grados. 


\begin{tabular}{|c|c|c|c|}
\hline $\begin{array}{l}\text { Instituto Politécnico de } \\
\text { Setúbal }\end{array}$ & Púb. & Comunicação Social & No \\
\hline $\begin{array}{l}\text { Instituto Politécnico de } \\
\text { Tomar }\end{array}$ & Púb. & Comunicaçáo Social & No \\
\hline \multirow{2}{*}{$\begin{array}{l}\text { Instituto Politécnico } \\
\text { de Viseu }\end{array}$} & \multirow{2}{*}{ Púb. } & Comunicação Social & No \\
\hline & & Publicidade e Relaçóes Públicas & No \\
\hline $\begin{array}{l}\text { Instituto Superior de } \\
\text { Estudos Interculturais } \\
\text { e Transdiciplinares de } \\
\text { Almada }\end{array}$ & Priv. & Ciências da Comunicação e Marketing & No \\
\hline $\begin{array}{l}\text { Instituto Superior de } \\
\text { Estudos Interculturais } \\
\text { e Transdiciplinares de } \\
\text { Mirandela } \\
\end{array}$ & Priv. & Ciências da Comunicação e Marketing & No \\
\hline $\begin{array}{l}\text { Instituto Superior } \\
\text { de Línguas e } \\
\text { Administraçáo de Leiria }\end{array}$ & Priv. & Comunicação & No \\
\hline $\begin{array}{l}\text { Instituto Superior } \\
\text { de Línguas e } \\
\text { Administração de } \\
\text { Santarém }\end{array}$ & Priv. & Comunicação & No \\
\hline $\begin{array}{l}\text { Instituto Superior } \\
\text { de Línguas e } \\
\text { Administração de Vila } \\
\text { Nova de Gaia } \\
\end{array}$ & Priv. & Comunicação & No \\
\hline \multirow{2}{*}{$\begin{array}{l}\text { Instituto Superior } \\
\text { Miguel Torga }\end{array}$} & \multirow{2}{*}{ Priv. } & Comunicação Empresarial & No \\
\hline & & Comunicaçāo Social & No \\
\hline $\begin{array}{l}\text { Universidad a Distancia } \\
\text { de Madrid }\end{array}$ & Púb. & Grado en Periodismo & No \\
\hline \multirow{6}{*}{$\begin{array}{l}\text { Universidad Antonio } \\
\text { de Nebrija }\end{array}$} & \multirow{6}{*}{ Priv. } & Grado en Comunicación audiovisual & No \\
\hline & & Grado en Periodismo & No \\
\hline & & Grado en Publicidad & No \\
\hline & & Licenciado en Comunicación Audiovisual & $\mathrm{Si}$ \\
\hline & & Licenciado en Periodismo & $\mathrm{Si}$ \\
\hline & & $\begin{array}{l}\text { Licenciado en Publicidad y Relaciones } \\
\text { Públicas }\end{array}$ & $\mathrm{Si}$ \\
\hline \multirow{3}{*}{$\begin{array}{l}\text { Universidad Autónoma } \\
\text { de Barcelona }\end{array}$} & \multirow{3}{*}{ Púb. } & Licenciado en Comunicación Audiovisual & $\mathrm{Si}$ \\
\hline & & Licenciado en Periodismo & $\mathrm{Si}$ \\
\hline & & $\begin{array}{l}\text { Licenciado en Publicidad y Relaciones } \\
\text { Públicas }\end{array}$ & $\mathrm{Si}$ \\
\hline $\begin{array}{l}\text { Universidad Autónoma } \\
\text { de Madrid }\end{array}$ & Púb. & $\begin{array}{l}\text { Grado en Lenguas Modernas, Cultura y } \\
\text { Comunicación }\end{array}$ & No \\
\hline \multirow{3}{*}{$\begin{array}{l}\text { Universidad Camilo } \\
\text { José Cela }\end{array}$} & \multirow{3}{*}{ Priv. } & Licenciado en Comunicación Audiovisual & No \\
\hline & & Licenciado en Periodismo & No \\
\hline & & $\begin{array}{l}\text { Licenciado en Publicidad y Relaciones } \\
\text { Públicas }\end{array}$ & No \\
\hline
\end{tabular}




\begin{tabular}{|c|c|c|c|}
\hline \multirow{6}{*}{$\begin{array}{l}\text { Universidad Cardenal } \\
\text { Herrera-CEU }\end{array}$} & \multirow{6}{*}{ Priv. } & Grado en Comunicación Audiovisual & No \\
\hline & & Grado en Periodismo & No \\
\hline & & $\begin{array}{l}\text { Grado en Publicidad y Relaciones } \\
\text { Públicas }\end{array}$ & No \\
\hline & & Licenciado en Comunicación Audiovisual & $\mathrm{Si}$ \\
\hline & & Licenciado en Periodismo & $\mathrm{Si}$ \\
\hline & & $\begin{array}{l}\text { Licenciado en Publicidad y Relaciones } \\
\text { Públicas }\end{array}$ & $\mathrm{Si}$ \\
\hline \multirow{8}{*}{$\begin{array}{l}\text { Universidad Carlos III } \\
\text { de Madrid }\end{array}$} & \multirow{8}{*}{ Púb. } & $\begin{array}{l}\text { Doble Grado en Periodismo - } \\
\text { Comunicación Audiovisual }\end{array}$ & No \\
\hline & & $\begin{array}{l}\text { Grado en Administración de Empresas } \\
\text { y complemento en Comunicación } \\
\text { Audiovisual }\end{array}$ & No \\
\hline & & Grado en Comunicación audiovisual & No \\
\hline & & $\begin{array}{l}\text { Grado en Derecho y complemento en } \\
\text { Periodismo }\end{array}$ & No \\
\hline & & $\begin{array}{l}\text { Grado en Economía y complemento en } \\
\text { Periodismo }\end{array}$ & No \\
\hline & & Grado en Periodismo & No \\
\hline & & Licenciado en Comunicación Audiovisual & $\mathrm{Si}$ \\
\hline & & Licenciado en Periodismo & $\mathrm{Si}$ \\
\hline \multirow{6}{*}{$\begin{array}{l}\text { Universidad Católica } \\
\text { San Antonio }\end{array}$} & \multirow{6}{*}{ Priv. } & Grado en Comunicación audiovisual & No \\
\hline & & Grado en Periodismo & No \\
\hline & & Grado en Publicidad y relaciones públicas & No \\
\hline & & Licenciado en Comunicación Audiovisual & $\mathrm{Si}$ \\
\hline & & Licenciado en Periodismo & $\mathrm{Si}$ \\
\hline & & $\begin{array}{l}\text { Licenciado en Publicidad y Relaciones } \\
\text { Públicas }\end{array}$ & Si \\
\hline $\begin{array}{l}\text { Universidad Católica } \\
\text { Santa Teresa de Jesús }\end{array}$ & Priv. & Licenciado en Periodismo & $\mathrm{Si}$ \\
\hline \multirow{6}{*}{$\begin{array}{l}\text { Universidad } \\
\text { Complutense de } \\
\text { Madrid }\end{array}$} & \multirow{6}{*}{ Púb. } & Grado en Comunicación Audiovisual & $\begin{array}{l}\text { No hay } \\
\text { información }\end{array}$ \\
\hline & & Grado en Periodismo & $\begin{array}{l}\text { No hay } \\
\text { información }\end{array}$ \\
\hline & & $\begin{array}{l}\text { Grado en Publicidad y Relaciones } \\
\text { Públicas }\end{array}$ & $\begin{array}{l}\text { No hay } \\
\text { información }\end{array}$ \\
\hline & & Licenciado en Comunicación Audiovisual & $\mathrm{Si}$ \\
\hline & & Licenciado en Periodismo & $\mathrm{Si}$ \\
\hline & & $\begin{array}{l}\text { Licenciado en Publicidad y Relaciones } \\
\text { Públicas }\end{array}$ & $\mathrm{Si}$ \\
\hline $\begin{array}{l}\text { Universidad de A } \\
\text { Coruña }\end{array}$ & Púb. & Licenciado en Comunicación Audiovisual & No \\
\hline Universidad de Alicante & Púb. & $\begin{array}{l}\text { Licenciado en Publicidad y Relaciones } \\
\text { Públicas }\end{array}$ & $\mathrm{Si}$ \\
\hline \multirow{4}{*}{$\begin{array}{l}\text { Universidad de } \\
\text { Barcelona }\end{array}$} & \multirow{4}{*}{ Púb. } & Grado en Cine y Medios Audiovisuales & $\begin{array}{l}\text { No hay } \\
\text { información }\end{array}$ \\
\hline & & $\begin{array}{l}\text { Grado en Publicidad y Relaciones } \\
\text { Públicas }\end{array}$ & $\begin{array}{l}\text { No hay } \\
\text { información }\end{array}$ \\
\hline & & Licenciado en Comunicación Audiovisual & No \\
\hline & & $\begin{array}{l}\text { Licenciado en Publicidad y Relaciones } \\
\text { Públicas }\end{array}$ & Si \\
\hline
\end{tabular}




\begin{tabular}{|c|c|c|c|}
\hline \multirow[t]{2}{*}{ Universidad de Burgos } & \multirow[t]{2}{*}{ Púb. } & Grado en Comunicación Audiovisual & $\begin{array}{l}\text { No hay } \\
\text { información }\end{array}$ \\
\hline & & Licenciado en Comunicación Audiovisual & Si \\
\hline Universidad de Cádiz & Púb. & $\begin{array}{l}\text { Licenciado en Publicidad y Relaciones } \\
\text { Públicas }\end{array}$ & No \\
\hline Universidad de Deusto & Priv. & Grado en Comunicación & $\begin{array}{l}\text { No hay } \\
\text { información }\end{array}$ \\
\hline \multirow{2}{*}{$\begin{array}{l}\text { Universidad de } \\
\text { Extremadura }\end{array}$} & \multirow{2}{*}{ Púb. } & Grado en Comunicación Audiovisual & $\mathrm{Si}$ \\
\hline & & Licenciado en Comunicación Audiovisual & $\mathrm{Si}$ \\
\hline \multirow{2}{*}{ Universidad de Girona } & \multirow{2}{*}{ Púb. } & Grado en Comunicación Cultural & $\begin{array}{l}\text { No hay } \\
\text { información }\end{array}$ \\
\hline & & $\begin{array}{l}\text { Licenciado en Publicidad y Relaciones } \\
\text { Públicas }\end{array}$ & Si \\
\hline $\begin{array}{l}\text { Universidad de } \\
\text { Granada }\end{array}$ & Púb. & Licenciado en Comunicación Audiovisual & No \\
\hline \multirow{2}{*}{$\begin{array}{l}\text { Universidad de La } \\
\text { Laguna }\end{array}$} & \multirow{2}{*}{ Púb. } & Grado en Periodismo & $\mathrm{Si}$ \\
\hline & & Licenciado en Periodismo & No \\
\hline \multirow[t]{2}{*}{ Universidad de Lleida } & \multirow[t]{2}{*}{ Púb. } & $\begin{array}{l}\text { Grado en Comunicación y Periodismo } \\
\text { Audiovisuales }\end{array}$ & No \\
\hline & & Licenciado en Comunicación Audiovisual & No \\
\hline \multirow{3}{*}{ Universidad de Málaga } & \multirow{3}{*}{ Púb. } & Licenciado en Comunicación Audiovisual & $\mathrm{Si}$ \\
\hline & & Licenciado en Periodismo & $\mathrm{Si}$ \\
\hline & & $\begin{array}{l}\text { Licenciado en Publicidad y Relaciones } \\
\text { Públicas }\end{array}$ & Si \\
\hline \multirow{6}{*}{ Universidad de Murcia } & \multirow{6}{*}{ Púb. } & Grado en Comunicación audiovisual & $\begin{array}{l}\text { No hay } \\
\text { información }\end{array}$ \\
\hline & & Grado en Periodismo & $\begin{array}{l}\text { No hay } \\
\text { información }\end{array}$ \\
\hline & & $\begin{array}{l}\text { Grado en Publicidad y Relaciones } \\
\text { Públicas }\end{array}$ & $\begin{array}{l}\text { No hay } \\
\text { información }\end{array}$ \\
\hline & & Licenciado en Comunicación Audiovisual & No \\
\hline & & Licenciado en Periodismo & No \\
\hline & & $\begin{array}{l}\text { Licenciado en Publicidad y Relaciones } \\
\text { Públicas }\end{array}$ & No \\
\hline \multirow{6}{*}{ Universidad de Navarra } & \multirow{6}{*}{ Priv. } & Grado en Comunicación Audiovisual & No \\
\hline & & Grado en Periodismo & No \\
\hline & & $\begin{array}{l}\text { Grado en Publicidad y Relaciones } \\
\text { Públicas }\end{array}$ & No \\
\hline & & Licenciado en Comunicación Audiovisual & Si \\
\hline & & Licenciado en Periodismo & $\mathrm{Si}$ \\
\hline & & $\begin{array}{l}\text { Licenciado en Publicidad y Relaciones } \\
\text { Públicas }\end{array}$ & Si \\
\hline $\begin{array}{l}\text { Universidad de } \\
\text { Salamanca }\end{array}$ & Púb. & Licenciado en Comunicación Audiovisual & No \\
\hline \multirow{4}{*}{$\begin{array}{l}\text { Universidad } \\
\text { de Santiago de } \\
\text { Compostela }\end{array}$} & \multirow{4}{*}{ Púb. } & Grado en Comunicación Audiovisual & No \\
\hline & & Grado en Periodismo & $\mathrm{Si}$ \\
\hline & & Licenciado en Comunicación Audiovisual & Si \\
\hline & & Licenciado en Periodismo & $\mathrm{Si}$ \\
\hline
\end{tabular}




\begin{tabular}{|c|c|c|c|}
\hline \multirow{3}{*}{ Universidad de Sevilla } & \multirow{3}{*}{ Púb. } & Licenciado en Comunicación Audiovisual & $\mathrm{Si}$ \\
\hline & & Licenciado en Periodismo & $\mathrm{Si}$ \\
\hline & & $\begin{array}{l}\text { Licenciado en Publicidad y Relaciones } \\
\text { Públicas }\end{array}$ & $\mathrm{Si}$ \\
\hline \multirow{2}{*}{$\begin{array}{l}\text { Universidad de } \\
\text { Valencia (Estudi } \\
\text { General de València) }\end{array}$} & \multirow{2}{*}{ Púb. } & Licenciado en Comunicación Audiovisual & $\mathrm{Si}$ \\
\hline & & Licenciado en Periodismo & Si \\
\hline \multirow[b]{2}{*}{$\begin{array}{l}\text { Universidad de } \\
\text { Valladolid }\end{array}$} & \multirow[b]{2}{*}{ Púb. } & Licenciado en Periodismo & $\mathrm{Si}$ \\
\hline & & $\begin{array}{l}\text { Licenciado en Publicidad y Relaciones } \\
\text { Públicas }\end{array}$ & Si \\
\hline \multirow{6}{*}{ Universidad de Vic } & \multirow{6}{*}{ Priv. } & Grado en Comunicación Audiovisual & No \\
\hline & & Grado en Periodismo & No \\
\hline & & $\begin{array}{l}\text { Grado en Publicidad y Relaciones } \\
\text { Públicas }\end{array}$ & No \\
\hline & & Licenciado en Comunicación Audiovisual & Si \\
\hline & & Licenciado en Periodismo & $\mathrm{Si}$ \\
\hline & & $\begin{array}{l}\text { Licenciado en Publicidad y Relaciones } \\
\text { Públicas }\end{array}$ & Si \\
\hline \multirow{4}{*}{ Universidad de Vigo } & \multirow{4}{*}{ Púb. } & Grado en Comunicación Audiovisual & No \\
\hline & & $\begin{array}{l}\text { Grado en Publicidad y Relaciones } \\
\text { Públicas }\end{array}$ & No \\
\hline & & Licenciado en Comunicación Audiovisual & $\mathrm{Si}$ \\
\hline & & $\begin{array}{l}\text { Licenciado en Publicidad y Relaciones } \\
\text { Públicas }\end{array}$ & Si \\
\hline $\begin{array}{l}\text { Universidad de } \\
\text { Zaragoza }\end{array}$ & Púb. & Grado en Periodismo & $\mathrm{Si}$ \\
\hline \multirow{3}{*}{$\begin{array}{l}\text { Universidad del País } \\
\text { Vasco/Euskal Herriko } \\
\text { Unibertsitatea }\end{array}$} & \multirow{3}{*}{ Púb. } & Licenciado en Comunicación Audiovisual & $\mathrm{Si}$ \\
\hline & & Licenciado en Periodismo & $\mathrm{Si}$ \\
\hline & & $\begin{array}{l}\text { Licenciado en Publicidad y Relaciones } \\
\text { Públicas }\end{array}$ & $\mathrm{Si}$ \\
\hline \multirow{10}{*}{$\begin{array}{l}\text { Universidad Europea } \\
\text { de Madrid }\end{array}$} & \multirow{10}{*}{ Priv. } & $\begin{array}{l}\text { Doble Grado en Comunicación } \\
\text { Publicitaria - Comunicación Audiovisual } \\
\text { y Multimedia }\end{array}$ & No \\
\hline & & $\begin{array}{l}\text { Doble Grado en Márketing y Dirección } \\
\text { Comercial - Comunicación Publicitaria }\end{array}$ & $\begin{array}{l}\text { No hay } \\
\text { información }\end{array}$ \\
\hline & & $\begin{array}{l}\text { Doble Grado en Periodismo - } \\
\text { Comunicación Audiovisual y Multimedia }\end{array}$ & No \\
\hline & & $\begin{array}{l}\text { Grado en Comunicación audiovisual y } \\
\text { multimedia }\end{array}$ & No \\
\hline & & Grado en Comunicación publicitaria & No \\
\hline & & Grado en Periodismo & No \\
\hline & & Licenciado en Comunicación Audiovisual & $\mathrm{Si}$ \\
\hline & & Licenciado en Periodismo & $\mathrm{Si}$ \\
\hline & & $\begin{array}{l}\text { Licenciado en Publicidad y Relaciones } \\
\text { Públicas }\end{array}$ & $\mathrm{Si}$ \\
\hline & & $\begin{array}{l}\text { Triple Grado en Periodismo - } \\
\text { Comunicación Audiovisual y Multimedia } \\
\text { - Comunicación Publicitaria }\end{array}$ & No \\
\hline
\end{tabular}




\begin{tabular}{|c|c|c|c|}
\hline \multirow{6}{*}{$\begin{array}{l}\text { Universidad Europea } \\
\text { Miguel de Cervantes }\end{array}$} & \multirow{6}{*}{ Priv. } & Grado en Comunicación Audiovisual & No \\
\hline & & Grado en Periodismo & No \\
\hline & & $\begin{array}{l}\text { Grado en Publicidad y Relaciones } \\
\text { Públicas }\end{array}$ & No \\
\hline & & Licenciado en Comunicación Audiovisual & Si \\
\hline & & Licenciado en Periodismo & $\mathrm{Si}$ \\
\hline & & $\begin{array}{l}\text { Licenciado en Publicidad y Relaciones } \\
\text { Públicas }\end{array}$ & $\mathrm{Si}$ \\
\hline \multirow{6}{*}{$\begin{array}{l}\text { Universidad Francisco } \\
\text { de Vitoria }\end{array}$} & \multirow{6}{*}{ Priv. } & Grado en Comunicación Audiovisual & $\begin{array}{l}\text { No facilita } \\
\text { información } \\
\text { en la web }\end{array}$ \\
\hline & & Grado en Periodismo & $\begin{array}{l}\text { No facilita } \\
\text { información } \\
\text { en la web }\end{array}$ \\
\hline & & Grado en Publicidad & $\begin{array}{l}\text { No facilita } \\
\text { información } \\
\text { en la web }\end{array}$ \\
\hline & & Licenciado en Comunicación Audiovisual & Si \\
\hline & & Licenciado en Periodismo & $\mathrm{Si}$ \\
\hline & & $\begin{array}{l}\text { Licenciado en Publicidad y Relaciones } \\
\text { Públicas }\end{array}$ & $\mathrm{Si}$ \\
\hline \multirow{4}{*}{$\begin{array}{l}\text { Universidad } \\
\text { Internacional de } \\
\text { Cataluña }\end{array}$} & \multirow{4}{*}{ Priv. } & Grado en Comunicación Audiovisual & $\begin{array}{l}\text { No. Solo } \\
\text { facilita } \\
\text { información } \\
\text { de 1er } \\
\text { curso } \\
\end{array}$ \\
\hline & & $\begin{array}{l}\text { Grado en Publicidad y Relaciones } \\
\text { Públicas }\end{array}$ & $\begin{array}{l}\text { No. Solo } \\
\text { facilita } \\
\text { información } \\
\text { de 1er } \\
\text { curso } \\
\end{array}$ \\
\hline & & Licenciado en Comunicación Audiovisual & $\mathrm{Si}$ \\
\hline & & Licenciado en Periodismo ( $2^{\circ}$ ciclo $)$ & No \\
\hline $\begin{array}{l}\text { Universidad } \\
\text { Internacional de La } \\
\text { Rioja }\end{array}$ & Priv. & Grado en Comunicación & No \\
\hline \multirow{3}{*}{$\begin{array}{l}\text { Universidad Miguel } \\
\text { Hernández de Elche }\end{array}$} & \multirow{3}{*}{ Púb. } & Licenciado en Comunicación Audiovisual & Si \\
\hline & & Licenciado en Periodismo & Si \\
\hline & & $\begin{array}{l}\text { Licenciado en Publicidad y Relaciones } \\
\text { Públicas }\end{array}$ & $\mathrm{Si}$ \\
\hline \multirow{2}{*}{$\begin{array}{l}\text { Universidad } \\
\text { Mondragón } \\
\text { Unibertsitatea }\end{array}$} & \multirow{2}{*}{ Priv. } & Grado en Comunicación Audiovisual & No \\
\hline & & Licenciado en Comunicación Audiovisual & $\mathrm{Si}$ \\
\hline \multirow{2}{*}{$\begin{array}{l}\text { Universidad Nacional } \\
\text { de Educación a } \\
\text { Distancia }\end{array}$} & \multirow{2}{*}{ Púb. } & Licenciado en Comunicación Audiovisual & Si \\
\hline & & Licenciado en Periodismo & $\mathrm{Si}$ \\
\hline $\begin{array}{l}\text { Universidad Politécnica } \\
\text { de Valencia }\end{array}$ & Púb. & Licenciado en Comunicación Audiovisual & Si \\
\hline
\end{tabular}




\begin{tabular}{|c|c|c|c|}
\hline \multirow{6}{*}{$\begin{array}{l}\text { Universidad Pompeu } \\
\text { Fabra }\end{array}$} & \multirow{6}{*}{ Púb. } & Grado en Comunicación audiovisual & No \\
\hline & & Grado en Periodismo & No \\
\hline & & $\begin{array}{l}\text { Grado en Publicidad y Relaciones } \\
\text { públicas }\end{array}$ & No \\
\hline & & Licenciado en Comunicación Audiovisual & No \\
\hline & & Licenciado en Periodismo & No \\
\hline & & $\begin{array}{l}\text { Licenciado en Publicidad y Relaciones } \\
\text { Públicas }\end{array}$ & Si \\
\hline \multirow{5}{*}{$\begin{array}{l}\text { Universidad Pontificia } \\
\text { de Salamanca }\end{array}$} & \multirow{5}{*}{ Priv. } & Grado en Periodismo & $\begin{array}{l}\text { No hay } \\
\text { información }\end{array}$ \\
\hline & & $\begin{array}{l}\text { Grado en Publicidad y Relaciones } \\
\text { Públicas }\end{array}$ & $\begin{array}{l}\text { No hay } \\
\text { información }\end{array}$ \\
\hline & & Licenciado en Comunicación Audiovisual & $\mathrm{Si}$ \\
\hline & & Licenciado en Periodismo & $\mathrm{Si}$ \\
\hline & & $\begin{array}{l}\text { Licenciado en Publicidad y Relaciones } \\
\text { Públicas }\end{array}$ & $\mathrm{Si}$ \\
\hline \multirow{6}{*}{$\begin{array}{l}\text { Universidad Ramon } \\
\text { Llull }\end{array}$} & \multirow{6}{*}{ Priv. } & Grado en Cine y televisión & No \\
\hline & & Grado en Periodismo & No \\
\hline & & Grado en Publicidad y relaciones públicas & No \\
\hline & & Licenciado en Comunicación Audiovisual & $\mathrm{Si}$ \\
\hline & & Licenciado en Periodismo & $\mathrm{Si}$ \\
\hline & & $\begin{array}{l}\text { Licenciado en Publicidad y Relaciones } \\
\text { Públicas }\end{array}$ & Si \\
\hline \multirow{8}{*}{$\begin{array}{l}\text { Universidad Rey Juan } \\
\text { Carlos }\end{array}$} & \multirow{8}{*}{ Púb. } & $\begin{array}{l}\text { Doble Grado en Comunicación } \\
\text { Audiovisual - Periodismo }\end{array}$ & $\mathrm{Si}$ \\
\hline & & Doble Grado en Periodismo e Historia & $\mathrm{Si}$ \\
\hline & & Grado en Comunicación audiovisual & $\mathrm{Si}$ \\
\hline & & Grado en Periodismo & $\mathrm{Si}$ \\
\hline & & $\begin{array}{l}\text { Grado en Publicidad y Relaciones } \\
\text { Públicas }\end{array}$ & $\mathrm{Si}$ \\
\hline & & Licenciado en Comunicación Audiovisual & $\mathrm{Si}$ \\
\hline & & Licenciado en Periodismo & $\mathrm{Si}$ \\
\hline & & $\begin{array}{l}\text { Licenciado en Publicidad y Relaciones } \\
\text { Públicas }\end{array}$ & $\mathrm{Si}$ \\
\hline \multirow{6}{*}{$\begin{array}{l}\text { Universidad Rovira i } \\
\text { Virgili }\end{array}$} & \multirow{6}{*}{ Púb. } & Grado en Comunicación Audiovisual & No \\
\hline & & Grado en Periodismo & No \\
\hline & & $\begin{array}{l}\text { Grado en Publicidad y Relaciones } \\
\text { Públicas }\end{array}$ & No \\
\hline & & Licenciado en Periodismo & No \\
\hline & & Licenciado en periodismo (segundo ciclo) & No \\
\hline & & $\begin{array}{l}\text { Licenciado en Publicidad y Relaciones } \\
\text { Públicas }\end{array}$ & $\mathrm{Si}$ \\
\hline \multirow{5}{*}{ Universidad San Jorge } & \multirow{5}{*}{ Priv. } & Grado en Comunicación audiovisual & No \\
\hline & & Grado en Periodismo & $\mathrm{Si}$ \\
\hline & & Grado en Publicidad y relaciones públicas & No \\
\hline & & Licenciado en Periodismo & Si \\
\hline & & $\begin{array}{l}\text { Licenciado en Publicidad y Relaciones } \\
\text { Públicas }\end{array}$ & $\mathrm{Si}$ \\
\hline
\end{tabular}




\begin{tabular}{|c|c|c|c|}
\hline \multirow{6}{*}{$\begin{array}{l}\text { Universidad San Pablo- } \\
\text { CEU }\end{array}$} & \multirow{6}{*}{ Priv. } & Grado en Comunicación Audiovisual & No \\
\hline & & Grado en Periodismo & No \\
\hline & & $\begin{array}{l}\text { Grado en Publicidad y Relaciones } \\
\text { Públicas }\end{array}$ & No \\
\hline & & Licenciado en Comunicación Audiovisual & No \\
\hline & & Licenciado en Periodismo & $\mathrm{Si}$ \\
\hline & & $\begin{array}{l}\text { Licenciado en Publicidad y Relaciones } \\
\text { Públicas }\end{array}$ & $\begin{array}{l}\text { No hay } \\
\text { información }\end{array}$ \\
\hline \multirow[t]{2}{*}{$\begin{array}{l}\text { Universidade Católica } \\
\text { Portuguesa }\end{array}$} & \multirow[t]{2}{*}{ Cat. } & $\begin{array}{l}\text { Comunicação Social e Cultural (con } \\
\text { especialidades en Comunicaçâo Social } \\
\text { / Jornalismo, Comunicaçāo Cultural, } \\
\text { Comunicaçáo Digital, Comunicaçáo } \\
\text { Visual, Comunicaçăo Organizacional) }\end{array}$ & No \\
\hline & & Ciências da Comunicaçấo & No \\
\hline $\begin{array}{l}\text { Universidade da Beira } \\
\text { Interior }\end{array}$ & Púb. & Ciências da Comunicação & No \\
\hline $\begin{array}{l}\text { Universidade de } \\
\text { Coimbra }\end{array}$ & Púb. & Jornalismo & No \\
\hline \multirow{2}{*}{$\begin{array}{l}\text { Universidade de } \\
\text { Trás-os-Montes e Alto } \\
\text { Douro }\end{array}$} & \multirow{2}{*}{ Púb. } & Ciências da Comunicaçấo & No \\
\hline & & Comunicação e Multimédia & No \\
\hline $\begin{array}{l}\text { Universidade do } \\
\text { Algarve }\end{array}$ & Púb. & Ciências da Comunicação & No \\
\hline Universidade do Minho & Púb. & Ciências da Comunicação & No \\
\hline Universidade do Porto & Púb. & $\begin{array}{l}\text { Ciências da Comunicação: Jornalismo, } \\
\text { Assessoria, Multimédia }\end{array}$ & No \\
\hline $\begin{array}{l}\text { Universidade dos } \\
\text { Açores }\end{array}$ & Púb. & Comunicaçáo Social e Cultura & No \\
\hline $\begin{array}{l}\text { Universidade Fernando } \\
\text { Pessoa }\end{array}$ & Priv. & Ciências da Comunicaçấo & No \\
\hline \multirow[t]{3}{*}{$\begin{array}{l}\text { Universidade Lusófona } \\
\text { do Porto }\end{array}$} & \multirow[t]{3}{*}{ Priv. } & $\begin{array}{l}\text { Ciências da Comunicação e da } \\
\text { Cultura (Comunicação e Jornalismo, } \\
\text { Comunicação Aplicada: Marketing, } \\
\text { Publicidade e Relaçôes Públicas, Gestão } \\
\text { Cultural) }\end{array}$ & No \\
\hline & & Comunicação Audiovisual e Multimédia & No \\
\hline & & Design de Comunicaçáo & No \\
\hline $\begin{array}{l}\text { Universidade Nova de } \\
\text { Lisboa }\end{array}$ & Púb. & Ciências da Comunicaçáo & No \\
\hline $\begin{array}{l}\text { Universidade Técnica } \\
\text { de Lisboa }\end{array}$ & Púb. & Ciências da Comunicação & No \\
\hline \multirow{4}{*}{$\begin{array}{l}\text { Universitat Abat Oliba } \\
\text { CEU }\end{array}$} & \multirow{4}{*}{ Priv. } & Grado en Periodismo & $\mathrm{Si}$ \\
\hline & & $\begin{array}{l}\text { Grado en Publicidad y Relaciones } \\
\text { Públicas }\end{array}$ & $\mathrm{Si}$ \\
\hline & & Licenciado en Periodismo & $\mathrm{Si}$ \\
\hline & & $\begin{array}{l}\text { Licenciado en Publicidad y Relaciones } \\
\text { Públicas }\end{array}$ & $\mathrm{Si}$ \\
\hline \multirow{3}{*}{$\begin{array}{l}\text { Universitat de las Illes } \\
\text { Balears }\end{array}$} & \multirow{3}{*}{ Púb. } & Grado en Comunicación Audiovisual & No \\
\hline & & Grado en Periodismo & No \\
\hline & & Licenciado en Comunicación Audiovisual & $\mathrm{Si}$ \\
\hline
\end{tabular}




\begin{tabular}{|c|c|c|c|}
\hline \multirow{4}{*}{$\begin{array}{l}\text { Universitat de València } \\
\text { (Estudi General) }\end{array}$} & \multirow{4}{*}{ Púb. } & Grado en Comunicación Audiovisual & No \\
\hline & & Grado en Periodismo & No \\
\hline & & Licenciado en Comunicación Audiovisual & Si \\
\hline & & Licenciado en Periodismo & Si \\
\hline \multirow{5}{*}{$\begin{array}{l}\text { Universitat Jaume I de } \\
\text { Castellón }\end{array}$} & \multirow{5}{*}{ Púb. } & Grado en Comunicación Audiovisual & $\mathrm{Si}$ \\
\hline & & Grado en Periodismo & $\mathrm{Si}$ \\
\hline & & $\begin{array}{l}\text { Grado en Publicidad y Relaciones } \\
\text { Públicas }\end{array}$ & Si \\
\hline & & Licenciado en Comunicación Audiovisual & Si \\
\hline & & $\begin{array}{l}\text { Licenciado en Publicidad y Relaciones } \\
\text { Públicas }\end{array}$ & Si \\
\hline \multirow{3}{*}{$\begin{array}{l}\text { Universitat Oberta de } \\
\text { Catalunya }\end{array}$} & \multirow{3}{*}{ Priv. } & Grado en Comunicación & No \\
\hline & & Licenciado en Comunicación Audiovisual & No \\
\hline & & $\begin{array}{l}\text { Licenciado en Publicidad y Relaciones } \\
\text { Públicas }\end{array}$ & No \\
\hline
\end{tabular}

\subsection{Características relevantes de las materias relacionadas con la Documentación Informativa ofertadas en las universidades espańolas y portuguesas}

Tabela 3 - Las asignaturas relacionadas con la materia Documentación Informativa ofertadas en las universidades españolas y portuguesas

\begin{tabular}{|c|c|c|c|}
\hline $\begin{array}{l}\text { Denominación de } \\
\text { la asignatura }\end{array}$ & Titulación académica & $\begin{array}{l}\text { Tipo, curso y } \\
\text { créditos }\end{array}$ & Descripción y contenidos \\
\hline $\begin{array}{l}\text { Biblioteconomia, } \\
\text { Arquivo e } \\
\text { Documentação }\end{array}$ & $\begin{array}{l}\text { Educação e } \\
\text { Comunicaçãoo } \\
\text { Multimédia } \\
\end{array}$ & $\begin{array}{l}\text { Tronco común; } \\
3^{\text {er }} \text { curso; } 6 \mathrm{cr}\end{array}$ & \\
\hline Documentación & $\begin{array}{l}\text { Licenciado en } \\
\text { Periodismo/ Publicidad } \\
\text { y Relaciones Públicas; } \\
\text { Grado en } \\
\text { Comunicación } \\
\text { Audiovisual/ Grado } \\
\text { en Periodismo/ Grado } \\
\text { en Publicidad y } \\
\text { Relaciones Públicas } \\
\end{array}$ & $\begin{array}{l}\text { Troncal/ } \\
\text { Obligatoria; } \\
20 / 3^{\circ} \text { curso; } \\
6 \mathrm{cr} \text {. }\end{array}$ & $\begin{array}{l}\text { Estudio y análisis de los sistemas } \\
\text { de documentación utilizados en los } \\
\text { medios de comunicación. } \\
\text { Estudio y análisis de los sistemas } \\
\text { de documentación específicos de la } \\
\text { Publicidad y las Relaciones Públicas. }\end{array}$ \\
\hline $\begin{array}{l}\text { Documentación } \\
\text { en los medios de } \\
\text { comunicación }\end{array}$ & $\begin{array}{l}\text { Licenciado en } \\
\text { Comunicación } \\
\text { Audiovisual } \\
\end{array}$ & $\begin{array}{l}\text { Troncal; } \\
3^{\circ} . \text { Curso; } 6 \mathrm{cr} \text {. }\end{array}$ & $\begin{array}{l}\text { Estudio y análisis de los sistemas } \\
\text { de documentación utilizados en los } \\
\text { medios de comunicación }\end{array}$ \\
\hline $\begin{array}{l}\text { Sistemas de } \\
\text { Informação }\end{array}$ & $\begin{array}{l}\text { Educação e } \\
\text { Comunicaçáao } \\
\text { Multimédia } \\
\end{array}$ & $\begin{array}{l}\text { Tronco común; } \\
2^{\circ} \text { curso; } 4,5 \mathrm{cr} \text {. }\end{array}$ & \\
\hline $\begin{array}{l}\text { Sistemas de } \\
\text { Informação On- } \\
\text { Line }\end{array}$ & $\begin{array}{l}\text { Educação e } \\
\text { Comunicaçãoo } \\
\text { Multimédia } \\
\end{array}$ & $\begin{array}{l}\text { Tronco común; } \\
2^{\circ} \text { curso; } 3 \mathrm{cr} \text {. }\end{array}$ & \\
\hline
\end{tabular}




\begin{tabular}{|c|c|c|c|}
\hline $\begin{array}{l}\text { Documentación } \\
\text { informativa }\end{array}$ & \begin{tabular}{|l|} 
Licenciado en \\
Periodismo// \\
Comunicación \\
Audiovisual/ \\
Publicidad y Relaciones \\
Públicas; \\
Grado en Periodismo/ \\
Comunicación \\
Audiovisual/ \\
Publicidad y Relaciones \\
Públicas; \\
Doble Grado en \\
Comunicación \\
Audiovisual - \\
Periodismo/ \\
Doble Grado en \\
Periodismo e Historia \\
\end{tabular} & $\begin{array}{l}\text { Troncal/ } \\
\text { Obligatoria; } \\
1^{\text {er }} / 2^{\circ} / 3^{\circ} \text { curso; } \\
6 \text { cr. } / 9 \text { cr. }\end{array}$ & $\begin{array}{l}\text { Estudio y análisis de los sistemas } \\
\text { de documentación utilizados en los } \\
\text { medios de comunicación }\end{array}$ \\
\hline $\begin{array}{l}\text { Documentación } \\
\text { periodística }\end{array}$ & $\begin{array}{l}\text { Licenciado en } \\
\text { Periodismo }\end{array}$ & $\begin{array}{l}\text { Troncal/ } \\
\text { Obligatoria/ } \\
\text { Optativa; } 1^{\text {er }} \\
\text { ciclo/ 20 ciclo; } \\
6 \text { cr. } 7,5 \text { cr. / 4,5 } \\
\text { cr./ } 4 \text { cr. }\end{array}$ & $\begin{array}{l}\text { Estudio y análisis de los sistemas } \\
\text { de documentación utilizados en los } \\
\text { medios de comunicación/ } \\
\text { Estudio y análisis de los sistemas } \\
\text { de documentación específicos del } \\
\text { periodismo/ } \\
\text { Naturaleza, concepto y aplicaciones } \\
\text { de la Documentación al proceso } \\
\text { informativo de carácter periodístico/ } \\
\text { Fuentes de la información. Archivos. } \\
\text { Departamentos y clasificación de } \\
\text { datos y referencias/ } \\
\text { Estudio de los diversos sistemas } \\
\text { de organización y archivo de la } \\
\text { documentación publicitaria }\end{array}$ \\
\hline $\begin{array}{l}\text { Documentación } \\
\text { comunicativa }\end{array}$ & $\begin{array}{l}\text { Grado en } \\
\text { Comunicación } \\
\text { audiovisual/ } \\
\text { Periodismo } \\
\end{array}$ & $\begin{array}{l}\text { Formación } \\
\text { básica; } 1^{\circ} \text { curso }\end{array}$ & \\
\hline $\begin{array}{l}\text { Documentación } \\
\text { y comunicación } \\
\text { audiovisual }\end{array}$ & \begin{tabular}{|l|} 
Grado en \\
Comunicación \\
audiovisual \\
\end{tabular} & $\begin{array}{l}\text { Formación } \\
\text { básica; } 1^{\text {er }} \text { curso; } \\
6 \text { cr. } \\
\end{array}$ & \\
\hline $\begin{array}{l}\text { Gestión de la } \\
\text { información }\end{array}$ & $\begin{array}{l}\text { Grado en Periodismo/ } \\
\text { Cine y televisión/ } \\
\text { Publicidad y relaciones } \\
\text { públicas l }\end{array}$ & $\begin{array}{l}\text { Formación } \\
\text { básica; } 1^{\text {er }} \text { curso; } \\
6 \text { cr. }\end{array}$ & \\
\hline $\begin{array}{l}\text { Búsqueda y } \\
\text { recuperación de } \\
\text { la información }\end{array}$ & $\begin{array}{l}\text { Grado en } \\
\text { Comunicación }\end{array}$ & $\begin{array}{l}\text { Obligatoria; } 1^{\text {er }} \\
\text { curso; } 6 \text { cr. }\end{array}$ & \\
\hline $\begin{array}{l}\text { Comunicación } \\
\text { e información } \\
\text { periodística }\end{array}$ & \begin{tabular}{|l|} 
Grado en \\
Comunicación \\
Audiovisual \\
\end{tabular} & $\begin{array}{l}\text { Obligatoria; } 2^{\circ} \\
\text { curso; } 6 \mathrm{cr} \text {. }\end{array}$ & \\
\hline $\begin{array}{l}\text { Documentación } \\
\text { para la } \\
\text { información }\end{array}$ & $\begin{array}{l}\text { Grado en Publicidad y } \\
\text { Relaciones Públicas }\end{array}$ & $\begin{array}{l}\text { Obligatoria; } 1^{\text {er }} \\
\text { curso; } 6 \mathrm{cr} \text {. }\end{array}$ & \\
\hline
\end{tabular}




\begin{tabular}{|c|c|c|c|}
\hline $\begin{array}{l}\text { Documentación } \\
\text { e investigación } \\
\text { periodística }\end{array}$ & $\begin{array}{l}\text { Grado en Periodismo/ } \\
\text { Doble Grado } \\
\text { en Periodismo- } \\
\text { Comunicación } \\
\text { Audiovisual y } \\
\text { Multimedia/ Triple } \\
\text { Grado en Periodismo- } \\
\text { Comunicación } \\
\text { Audiovisual y } \\
\text { Multimedia- } \\
\text { Comunicación } \\
\text { Publicitaria/ } \\
\end{array}$ & $\begin{array}{l}\text { Obligatoria } \\
1^{\circ / 2} 2^{\circ} \text { curso / } \\
6 \mathrm{cr}\end{array}$ & \\
\hline $\begin{array}{l}\text { Documentación } \\
\text { en el diseño } \\
\text { de proyectos } \\
\text { audiovisuales }\end{array}$ & $\begin{array}{l}\text { Grado en } \\
\text { Comunicación } \\
\text { audiovisual y } \\
\text { multimedia }\end{array}$ & $\begin{array}{l}\text { Obligatoria; } 1^{\text {er }} \\
\text { curso; } 3 \text { cr. }\end{array}$ & \\
\hline $\begin{array}{l}\text { Documentación } \\
\text { publicitaria }\end{array}$ & $\begin{array}{l}\text { Grado en Publicidad y } \\
\text { relaciones públicas }\end{array}$ & $\begin{array}{l}\text { Obligatoria; } 1^{\text {er }} \\
\text { curso; } 6 \mathrm{cr} .\end{array}$ & \\
\hline $\begin{array}{l}\text { Documentación y } \\
\text { gestión de fuentes } \\
\text { de comunicación }\end{array}$ & $\begin{array}{l}\text { Grado en } \\
\text { Comunicación }\end{array}$ & $\begin{array}{l}\text { Obligatoria; } 4^{\circ} \\
\text { curso; } 4 \text { cr. }\end{array}$ & \\
\hline $\begin{array}{l}\text { Documentación y } \\
\text { nuevos soportes }\end{array}$ & Grado en Periodismo & $\begin{array}{l}\text { Obligatoria;. } 1^{\text {er }} \\
\text { curso; } 6 \text { cr. }\end{array}$ & \\
\hline $\begin{array}{l}\text { Documentación } \\
\text { y técnicas de } \\
\text { investigación } \\
\end{array}$ & \begin{tabular}{|l|} 
Grado en Periodismo / \\
Universidad San Pablo- \\
CEU
\end{tabular} & $\begin{array}{l}\text { Obligatoria; } 3^{\text {er }} \\
\text { curso; } 6 \text { cr. }\end{array}$ & \\
\hline $\begin{array}{l}\text { Educaçáo para os } \\
\text { Media e Gestão } \\
\text { da Informação } \\
\end{array}$ & Comunicação Social & $\begin{array}{l}\text { Obligatoria; } 1^{\mathrm{er}} \\
\text { curso; } 5 \mathrm{cr} \text {. }\end{array}$ & \\
\hline $\begin{array}{l}\begin{array}{l}\text { Fuentes de la } \\
\text { información } \\
\text { publicitaria }\end{array} \\
\end{array}$ & \begin{tabular}{|l|} 
Grado en \\
Comunicación \\
publicitaria \\
\end{tabular} & $\begin{array}{l}\text { Obligatoria; } 1^{\text {er }} \\
\text { curso; } \\
6 \text { cr. } \\
\end{array}$ & \\
\hline $\begin{array}{l}\text { Gestão da } \\
\text { Informação para a } \\
\text { Comunicaçấo }\end{array}$ & $\begin{array}{l}\text { Ciências da } \\
\text { Comunicação: } \\
\text { Jornalismo, Assessoria, } \\
\text { Multimédia }\end{array}$ & $\begin{array}{l}\text { Obligatoria; } 2^{\circ} \\
\text { curso; } 5 \mathrm{cr} \text {. }\end{array}$ & $\begin{array}{l}\text { Pretende-se que os alunos conheçam } \\
\text { a natureza da informação, } \\
\text { compreendam a sua importância } \\
\text { na sociedade actual e reconheçam } \\
\text { as infra-estruturas que potenciam } \\
\text { a construção e desenvolvimento } \\
\text { da sociedade da informação. } \\
\text { Pretende-se ainda que apreendam as } \\
\text { técnicas de recuperaçáo, avaliaçãa } \\
\text { e organização da informação, } \\
\text { independentemente do suporte em } \\
\text { que esteja registada, e entendam } \\
\text { a importância da gestão da } \\
\text { informação dentro de contextos } \\
\text { organizacionais } \\
\end{array}$ \\
\hline $\begin{array}{l}\text { Informaçáo Local } \\
\text { e Regional }\end{array}$ & Comunicação & $\begin{array}{l}\text { Obligatoria; } 3^{\text {er }} \\
\text { curso; } 4 \text { cr.. }\end{array}$ & \\
\hline $\begin{array}{l}\text { Organizaçáo de } \\
\text { Documentaçắo e } \\
\text { Arquivo } \\
\end{array}$ & $\begin{array}{l}\text { Comunicação Social e } \\
\text { Educação Multimédia }\end{array}$ & $\begin{array}{l}\text { Obligatoria; } 1^{\mathrm{er}} \\
\text { curso; } 6 \text { cr. }\end{array}$ & \\
\hline $\begin{array}{l}\text { Pesquisa } \\
\text { Documental e } \\
\text { Base de Dados }\end{array}$ & $\begin{array}{l}\text { Comunicaçáo Social e } \\
\text { Educaçáo Multimédia } \\
\text { (Pós-Laboral) }\end{array}$ & $\begin{array}{l}\text { Obligatoria; } 1^{\mathrm{er}} \\
\text { curso; } 6 \mathrm{cr} \text {. }\end{array}$ & \\
\hline
\end{tabular}




\begin{tabular}{|c|c|c|c|}
\hline $\begin{array}{l}\text { Pesquisa } \\
\text { Documental e } \\
\text { Base de Dados } \\
\end{array}$ & $\begin{array}{l}\text { Comunicaçáo Social e } \\
\text { Educação Multimédia }\end{array}$ & $\begin{array}{l}\text { Obligatoria; } 4^{\circ} \\
\text { curso; } 6 \text { cr. }\end{array}$ & \\
\hline $\begin{array}{l}\text { Recuperação } \\
\text { e Avaliaçăo da } \\
\text { Informação I }\end{array}$ & $\begin{array}{l}\text { Publicidade e Relaçóes } \\
\text { Públicas }\end{array}$ & $\begin{array}{l}\text { Obligatoria; } 1^{\text {er }} \\
\text { curso; } 4 \text { cr. }\end{array}$ & \\
\hline $\begin{array}{l}\text { Recuperação } \\
\text { e Avaliaçăo da } \\
\text { Informação II }\end{array}$ & $\begin{array}{l}\text { Publicidade e Relaçōes } \\
\text { Públicas }\end{array}$ & $\begin{array}{l}\text { Obligatoria; } 1^{\text {er }} \\
\text { curso; } 4 \text { cr.. }\end{array}$ & \\
\hline $\begin{array}{l}\text { Recuperaçáo } \\
\text { e Avaliação de } \\
\text { Informação }\end{array}$ & Comunicação Social & $\begin{array}{l}\text { Obligatoria; } 1^{\text {er }} \\
\text { curso; } 6 \text { cr. }\end{array}$ & \\
\hline $\begin{array}{l}\text { Redes e Sistemas } \\
\text { de Informaçáo } \\
\text { - CD-CO }\end{array}$ & \begin{tabular}{|l|} 
Comunicação \\
Social e Cultural \\
(con especialidades \\
en Comunicaçáo \\
Social/ Jornalismo, \\
Comunicação Cultural, \\
Comunicação Digital, \\
Comunicação \\
Visual, Comunicação \\
Organizacional
\end{tabular} & $\begin{array}{l}\text { Obligatoria (para } \\
\text { especialidades } \\
\text { Comunicaçáo } \\
\text { Digital (CD) y } \\
\text { Comunicaçâo } \\
\text { Organizacional } \\
\text { (CO)); } 3 \text { cr. }\end{array}$ & \\
\hline $\begin{array}{l}\text { Sistemas de } \\
\text { Informaçấo }\end{array}$ & \begin{tabular}{|l|} 
Comunicação e \\
Multimédia \\
\end{tabular} & $\begin{array}{l}\text { Obligatoria; } 2^{\circ} \\
\text { curso; } 5 \mathrm{cr} . \\
\end{array}$ & \\
\hline $\begin{array}{l}\text { Documentación } \\
\text { audiovisual }\end{array}$ & $\begin{array}{l}\text { Licenciado en } \\
\text { Comunicación } \\
\text { Audiovisual/ } \\
\text { Licenciado en } \\
\text { Publicidad y Relaciones } \\
\text { Públicas/ Grado } \\
\text { en Comunicación } \\
\text { audiovisual }\end{array}$ & $\begin{array}{l}\text { Obligatoria/ } \\
\text { Optativa. } 2^{\circ} \\
\text { ciclo/ } 4.5 \mathrm{cr} . / 6 \\
\text { cr. }\end{array}$ & $\begin{array}{l}\text { Valoración y selección de las fuentes } \\
\text { escritas y audiovisuales; Tratamiento } \\
\text { documental al acceso a dichas } \\
\text { fuentes, en especial a los archivos de } \\
\text { imágenes/ } \\
\text { Documentación específicamente } \\
\text { orientada a los medios } \\
\text { audiovisuales/ } \\
\text { Análisis documental de imágenes; } \\
\text { Evolución de la iconoteca, el análisis } \\
\text { documental visual, los bancos de } \\
\text { datos de audiovisuales: fototeca, } \\
\text { filmoteca, videoteca; Programas } \\
\text { informáticos de tratamiento y } \\
\text { recuperación de imágenes/ } \\
\text { Gestión documental en el } \\
\text { campo audiovisual. Fuentes de } \\
\text { información. Análisis documental. } \\
\text { Clasificación e indexación. } \\
\text { Descripción de contenidos. Servicios } \\
\text { de documentación en programas } \\
\text { informativos. Funcionalidad y } \\
\text { preservación de los recursos de } \\
\text { información. Digitalización de } \\
\text { fuentes documentales/ } \\
\text { Naturaleza, concepto y aplicaciones } \\
\text { de la Documentación al proceso } \\
\text { informativo audiovisual } \\
\end{array}$ \\
\hline $\begin{array}{l}\text { Bases de datos } \\
\text { documentales }\end{array}$ & \begin{tabular}{|l|} 
Licenciado en \\
Comunicación \\
Audiovisual \\
\end{tabular} & Optativa; 5 cr. & $\begin{array}{l}\text { Gestión de bases de datos, consultas } \\
\text { y mantenimiento de bases de datos } \\
\text { documentales }\end{array}$ \\
\hline
\end{tabular}




\begin{tabular}{|c|c|c|c|}
\hline $\begin{array}{l}\text { Búsqueda y } \\
\text { obtención de la } \\
\text { información en } \\
\text { internet }\end{array}$ & $\begin{array}{l}\text { Grado en } \\
\text { Comunicación } \\
\text { audiovisual y } \\
\text { multimedia } \\
\end{array}$ & $\begin{array}{l}\text { Optativa; } 4^{\circ} \\
\text { curso; } 6 \text { cr. }\end{array}$ & \\
\hline $\begin{array}{l}\text { Documentación } \\
\text { aplicada a la } \\
\text { traducción }\end{array}$ & $\begin{array}{l}\text { Licenciado en } \\
\text { Comunicación } \\
\text { Audiovisual }\end{array}$ & $\begin{array}{l}\text { Optativa; } 1 \text { er } \\
\text { ciclo; } 4 \text { cr. }\end{array}$ & $\begin{array}{l}\text { Técnicas de investigación } \\
\text { documental y uso de fuentes y su } \\
\text { aplicación específica a la traducción } \\
\text { e interpretación }\end{array}$ \\
\hline $\begin{array}{l}\text { Documentación } \\
\text { de los medios } \\
\text { audiovisuales } \\
\end{array}$ & \begin{tabular}{|l|} 
Licenciado en \\
Comunicación \\
Audiovisual \\
\end{tabular} & $\begin{array}{l}\text { Optativa; } 2^{\circ} \\
\text { ciclo; } 4 \text { cr. }\end{array}$ & $\begin{array}{l}\text { Estudio y análisis de los sistemas } \\
\text { de documentación específicos de la } \\
\text { comunicación audiovisual. }\end{array}$ \\
\hline $\begin{array}{l}\text { Documentación } \\
\text { de medios de } \\
\text { comunicación }\end{array}$ & $\begin{array}{l}\text { Licenciado en } \\
\text { Comunicación } \\
\text { Audiovisual }\end{array}$ & $\begin{array}{l}\text { Optativa; } 2^{\circ} \\
\text { ciclo; } 4,5 \text { cr. }\end{array}$ & $\begin{array}{l}\text { Análisis de los sistemas de } \\
\text { documentación en diferentes medios } \\
\text { de comunicación y de las nuevas } \\
\text { tecnologías de la información } \\
\text { documental }\end{array}$ \\
\hline $\begin{array}{l}\text { Documentación } \\
\text { digital en los } \\
\text { medios } \\
\end{array}$ & $\begin{array}{l}\text { Licenciado en } \\
\text { Periodismo }\end{array}$ & Optativa; $6 \mathrm{cr}$. & $\begin{array}{l}\text { Tratamiento y gestión electrónica } \\
\text { de la documentación en los medios } \\
\text { periodísticos }\end{array}$ \\
\hline $\begin{array}{l}\text { Documentación } \\
\text { e información } \\
\text { audiovisual }\end{array}$ & $\begin{array}{l}\text { Licenciado en } \\
\text { Comunicación } \\
\text { Audiovisual }\end{array}$ & $\begin{array}{l}\text { Optativa, } 2^{\circ} \\
\text { ciclo, } 4 \text { créditos }\end{array}$ & $\begin{array}{l}\text { Documentación en soportes } \\
\text { tradicionales y soportes electrónicos. } \\
\text { Manejo de redes y bases de datos. } \\
\text { Organización de redes y bases de } \\
\text { datos propias y especializadas para } \\
\text { las distintas tareas comunicativas } \\
\end{array}$ \\
\hline $\begin{array}{l}\text { Documentación } \\
\text { en los medios de } \\
\text { comunicación }\end{array}$ & $\begin{array}{l}\text { Licenciado en } \\
\text { Comunicación } \\
\text { Audiovisual }\end{array}$ & $\begin{array}{l}\text { Optativa; } 2^{\circ} \\
\text { ciclo; } 6 \text { cr. }\end{array}$ & $\begin{array}{l}\text { Documentación en medios digitales } \\
\text { en televisión, radio, internet y redes } \\
\text { corporativas. Indización y estrategias } \\
\text { de recuperación de la información } \\
\end{array}$ \\
\hline $\begin{array}{l}\text { Documentación } \\
\text { en publicidad } \\
\text { y relaciones } \\
\text { públicas } \\
\end{array}$ & $\begin{array}{l}\text { Grado en Publicidad y } \\
\text { relaciones públicas }\end{array}$ & Optativa; 4 cr. & \\
\hline $\begin{array}{l}\text { Documentación } \\
\text { para la Publicidad } \\
\text { y las Relaciones } \\
\text { Públicas } \\
\end{array}$ & $\begin{array}{l}\text { Licenciado en } \\
\text { Publicidad y Relaciones } \\
\text { Públicas }\end{array}$ & $\begin{array}{l}\text { Optativa; } 2^{\circ} . \\
\text { Ciclo; } 4 \text { cr. }\end{array}$ & $\begin{array}{l}\text { Estudio y análisis de los sistemas } \\
\text { de documentación específicos de la } \\
\text { Publicidad y las Relaciones Públicas. }\end{array}$ \\
\hline $\begin{array}{l}\text { Documentación } \\
\text { para los medios } \\
\text { de comunicación }\end{array}$ & $\begin{array}{l}\text { Grado en Periodismo/ } \\
\text { Comunicación } \\
\text { Audiovisual } \\
\end{array}$ & $\begin{array}{l}\text { Optativa; } 4^{\circ} \\
\text { curso; } 6 \mathrm{cr} \text {. }\end{array}$ & \\
\hline $\begin{array}{l}\text { Documentación } \\
\text { publicitaria }\end{array}$ & $\begin{array}{l}\text { Licenciado en } \\
\text { Publicidad y Relaciones } \\
\text { Públicas }\end{array}$ & $\begin{array}{l}\text { Optativa; } 1^{\text {er }} \\
\text { ciclo/ } 2^{\circ} \text { ciclo; } 6 \\
\text { cr./ } 4,5 \text { cr. }\end{array}$ & $\begin{array}{l}\text { Naturaleza, concepto y aplicaciones } \\
\text { de la Documentación al proceso } \\
\text { informativo para la Publicidad y las } \\
\text { Relaciones Públicas }\end{array}$ \\
\hline $\begin{array}{l}\text { Documentación } \\
\text { y patrimonio } \\
\text { audiovisual }\end{array}$ & $\begin{array}{l}\text { Licenciado en } \\
\text { Comunicación } \\
\text { Audiovisual }\end{array}$ & Optativa; 6 cr. & $\begin{array}{l}\text { Estudio y análisis de los sistemas } \\
\text { de documentación destinados a } \\
\text { la organización, conservación y } \\
\text { difusión del patrimonio audiovisual }\end{array}$ \\
\hline $\begin{array}{l}\text { Documentalismo } \\
\text { Visual e } \\
\text { Audiovisual }\end{array}$ & $\begin{array}{l}\text { Ciências da } \\
\text { Comunicaçâao }\end{array}$ & $\begin{array}{l}\text { Optativa; } 1^{\text {er }} \\
\text { curso; } 3 \text { cr. }\end{array}$ & \\
\hline $\begin{array}{l}\text { Estudio de } \\
\text { las fuentes } \\
\text { informativas }\end{array}$ & $\begin{array}{l}\text { Licenciado en } \\
\text { Comunicación } \\
\text { Audiovisual } \\
\end{array}$ & Optativa; 4,5 cr. & $\begin{array}{l}\text { Fuentes de información } \\
\text { periodísticas; Generación de noticias }\end{array}$ \\
\hline
\end{tabular}




\begin{tabular}{|c|c|c|c|}
\hline $\begin{array}{l}\text { Fuentes de } \\
\text { información } \\
\text { en economía y } \\
\text { empresa }\end{array}$ & $\begin{array}{l}\text { Licenciado en } \\
\text { Publicidad y Relaciones } \\
\text { Públicas }\end{array}$ & Optativa; 4,5 cr. & $\begin{array}{l}\text { Análisis de las fuentes de } \\
\text { información en Economía y } \\
\text { Empresa: Fuentes de referencias } \\
\text { primarias y secundarias y su } \\
\text { evaluación. La red Internet en } \\
\text { Economía y Empresa: Grupos } \\
\text { de noticias, listas de discusión. } \\
\text { Estrategias de investigación } \\
\end{array}$ \\
\hline $\begin{array}{l}\text { Fuentes } \\
\text { documentales en } \\
\text { Internet }\end{array}$ & $\begin{array}{l}\text { Licenciado en } \\
\text { Periodismo }\end{array}$ & Optativa $6 \mathrm{cr}$. & $\begin{array}{l}\text { Estudio y valoración del acceso, la } \\
\text { organización y la representación } \\
\text { de la información en Internet con } \\
\text { fines especializados. Análisis de } \\
\text { los documentos web, utilidades } \\
\text { documentales y procedimientos para } \\
\text { la investigación }\end{array}$ \\
\hline $\begin{array}{l}\text { Gestión de la } \\
\text { documentación }\end{array}$ & $\begin{array}{l}\text { Licenciado en } \\
\text { Comunicación } \\
\text { Audiovisual } \\
\end{array}$ & Optativa; 9 cr. & $\begin{array}{l}\text { Bases de datos. Contenidos. Gestión } \\
\text { de bases de datos }\end{array}$ \\
\hline $\begin{array}{l}\text { Gestión } \\
\text { documental }\end{array}$ & $\begin{array}{l}\text { Licenciado en } \\
\text { Comunicación } \\
\text { Audiovisual }\end{array}$ & $\begin{array}{l}\text { Optativa,; } 2^{\circ} \\
\text { ciclo; } 4,5 \mathrm{cr}\end{array}$ & $\begin{array}{l}\text { Fundamentos de bases de datos. } \\
\text { Gestores de bases de datos, } \\
\text { motores de búsqueda, gestión del } \\
\text { conocimiento. Gestión aplicada a la } \\
\text { información documental }\end{array}$ \\
\hline $\begin{array}{l}\text { Guión, } \\
\text { Documentación } \\
\text { y realización } \\
\text { radiofónica }\end{array}$ & $\begin{array}{l}\text { Licenciado en } \\
\text { Comunicación } \\
\text { Audiovisual }\end{array}$ & $\begin{array}{l}\text { Optativa; } 2^{\circ} \\
\text { ciclo; } 4 \text { cr. }\end{array}$ & \begin{tabular}{|l|} 
Documentación en soportes \\
tradicionales y soportes electrónicos. \\
Manejo de redes y bases de datos. \\
Organización de redes y bases de \\
datos propias y especializadas para \\
las distintas tareas comunicativas \\
\end{tabular} \\
\hline $\begin{array}{l}\text { Las fuentes de } \\
\text { la información } \\
\text { económica }\end{array}$ & $\begin{array}{l}\text { Licenciado en } \\
\text { Comunicación } \\
\text { Audiovisual }\end{array}$ & Optativa; 5 cr. & $\begin{array}{l}\text { La información económica. } \\
\text { Los sectores. Los datos } \\
\text { macroeconómicos. Las fuentes } \\
\text { estadísticas de los distintos } \\
\text { sectores. Información de áreas } \\
\text { geográficas. Estudios e informes. La } \\
\text { información económica en Internet. } \\
\text { La interpretación de los datos. } \\
\text { Instrumentos de análisis. }\end{array}$ \\
\hline $\begin{array}{l}\text { Métodos y } \\
\text { técnicas de } \\
\text { Investigación } \\
\text { periodística } \\
\end{array}$ & $\begin{array}{l}\text { Licenciado en } \\
\text { Publicidad y Relaciones } \\
\text { Públicas }\end{array}$ & Optativa; 6 cr. & \begin{tabular}{|l|} 
Estudio teórico-práctico de \\
los métodos y técnicas de la \\
investigación para la comunicación \\
periodística
\end{tabular} \\
\hline $\begin{array}{l}\text { Organizaçáo } \\
\text { de Serviços de } \\
\text { Documentaçấo e } \\
\text { Arquivo } \\
\end{array}$ & Comunicação Social & Optativa; 3 cr. & \\
\hline $\begin{array}{l}\text { Patrimonio } \\
\text { audiovisual }\end{array}$ & $\begin{array}{l}\text { Licenciado en } \\
\text { Comunicación } \\
\text { Audiovisual }\end{array}$ & $\begin{array}{l}\text { Optativa; } 2^{\circ} \\
\text { ciclo; } 6 \text { cr. }\end{array}$ & $\begin{array}{l}\text { Concepto, conservación, acceso } \\
\text { y difusión del patrimonio } \\
\text { audiovisual. Conversión a soporte } \\
\text { digital. Documentos audiovisuales } \\
\text { y recuperación de la memoria } \\
\text { histórica. } \\
\end{array}$ \\
\hline $\begin{array}{l}\text { Redes y sistemas } \\
\text { de información }\end{array}$ & \begin{tabular}{|l|} 
Licenciado en \\
Comunicación \\
Audiovisual/ \\
Publicidad y Relaciones \\
Públicas \\
\end{tabular} & Optativa; 6 cr. & $\begin{array}{l}\text { Conocimiento y explotación de } \\
\text { los recursos prácticos de las nuevas } \\
\text { redes y sistemas digitales (internet, } \\
\text { intranets) }\end{array}$ \\
\hline
\end{tabular}




\begin{tabular}{|c|c|c|c|}
\hline $\begin{array}{l}\text { Regulación } \\
\text { jurídica de la } \\
\text { documentación }\end{array}$ & $\begin{array}{l}\text { Licenciado en } \\
\text { Periodismo }\end{array}$ & $\begin{array}{l}\text { Optativa; } 2^{\circ} \\
\text { Ciclo; } 4,5 \text { cr. }\end{array}$ & $\begin{array}{l}\text { Regulación jurídica de bibliotecas, } \\
\text { archivos, bases de datos. El derecho } \\
\text { de acceso, sus límites. El periodista } \\
\text { y su derecho de investigación } \\
\end{array}$ \\
\hline $\begin{array}{l}\text { Servicios de } \\
\text { información } \\
\text { digital }\end{array}$ & \begin{tabular}{|l|} 
Licenciado en \\
Publicidad y Relaciones \\
Públicas
\end{tabular} & $\begin{array}{l}\text { Optativa; } 2^{\circ} \\
\text { ciclo; } 5 \text { cr. }\end{array}$ & \begin{tabular}{|l|} 
Introducción a la edición de \\
información digital. Diseño de \\
sistemas de información en Internet
\end{tabular} \\
\hline $\begin{array}{l}\text { Sistemas de } \\
\text { documentación } \\
\text { digital }\end{array}$ & Grado en Periodismo & Optativa; 6 cr. & \\
\hline $\begin{array}{l}\text { Sistemas de } \\
\text { gestión de la } \\
\text { documentación } \\
\text { audiovisual } \\
\end{array}$ & $\begin{array}{l}\text { Licenciado en } \\
\text { Comunicación } \\
\text { Audiovisual }\end{array}$ & $\begin{array}{l}\text { Optativa; } 1^{\text {er }} \\
\text { ciclo, } 6 \text { cr. }\end{array}$ & $\begin{array}{l}\text { Estudio y análisis de los sistemas } \\
\text { y de los procesos de gestión de } \\
\text { la documentación audiovisual en } \\
\text { organizaciones públicas y privadas }\end{array}$ \\
\hline $\begin{array}{l}\text { Sistemas de } \\
\text { Informação de } \\
\text { Marketing }\end{array}$ & $\begin{array}{l}\text { Publicidade e } \\
\text { Marketing }\end{array}$ & Optativa; 3,5 cr. & \\
\hline
\end{tabular}

\section{A modo de conclusión}

El análisis efectuado sobre las competencias documentales incluidas en los planes de estudio de las titulaciones del ámbito de las Ciencias de la Comunicación ofertadas en España y Portugal muestra que:

1. La Documentación Informativa es una disciplina ampliamente consolida dentro de las Ciencias de la Documentación, como especialidad científica y como materia curricular dentro de las titulaciones universitarias relacionadas con los medios de comunicación social.

2. En el contexto académico del EEES es recomendable fomentar la visibilización de los planes de estudios de las titulaciones similares para favorecer dinámicas de comparabilidad y reconocimiento mutuo, así como promover buenas prácticas relacionadas con la difusión detallada de los contenidos curriculares de las distintas asignaturas que los integran, en aras a favorecer el reconocimiento de las competencias adquiridas por los estudiantes de países distintos.

3. No obstante, el momento actual, marcado por la coexistencia de modelos de planes de estudios distintos, no favorece la realización de comparativas entre las ofertas formativas de los dos países objeto de estudio, pues el solapamiento de Planes de estudios distorsiona temporalmente la imagen proyectada de la situación estudiada.

\section{Referências bibliográficas}

Agencia Nacional de Evaluación de la Calidad y Acreditación (2005). Libro blanco. Títulos de grado en Comunicación. Madrid: ANECA, 2005. Disponible en http://www.aneca.es/ media/150336/libroblanco_comunicacion_def.pdf. Consultado el 11-07-09.

Alonso, Luis Enrique; Fernández Rodríguez, Carlos J. y Nyssen, José María (2009). El debate sobre las competencias: una investigación cualitativa en torno a la educación superior y el mercado de trabajo en España. Madrid: ANECA, Disponible en http://www.aneca.es/media/148145/ publi_competencias_090303.pdf. Consultado el 11-07-09. 
Aquesolo Vegas, J. A. (1996). De la documentación informativa al periodismo de precisión. Documentación de las Ciencias de la Información, 19, 1996, p. 11-42. Disponible en http://revistas.ucm.es/inf/02104210/articulos/DCIN9696110011A.PDF. Consultado el 25-07-09.

Bas Martín, N. (2006). La documentación informativa en el nuevo espacio europeo de educación superior: Reflexiones desde la didáctica. Revista General de Información y Documentación, 16, 2, 2006, p. 111-126. Disponible en http://revistas.ucm.es/byd/11321873/articulos/ RGID0606220111A.PDF. Consultado el 23-07-09.

González Quesada, A. (2003). La investigación en Documentación informativa en España. Documentación de las Ciencias de la Información, 26, 2003, p. 71-97. Disponible en http://revistas.ucm.es/inf/02104210/articulos/DCIN0303110071A.PDF, Consultado el 24-07-09.

López Yepes, A. (2007). e-DocuInfo: un portal de documentación informativa para la formación, investigación y producción multimedia en línea. Boletín de la $A N A B A D, 57,2,2007$, p. 49-70.

Rubio Lacoba, M. (2007). Documentación informativa en el periodismo digital. Madrid: Síntesis, 2007. 